\title{
The Contribution of National Income Inequality to Regional Economic Divergence
}

\section{Citation}

Manduca, Robert. 2019. The Contribution of National Income Inequality to Regional Economic Divergence. Social Forces, soz013. https://doi.org/10.1093/sf/soz013

\section{Permanent link}

http://nrs.harvard.edu/urn-3:HUL.InstRepos:40455849

\section{Terms of Use}

This article was downloaded from Harvard University's DASH repository, WARNING: No applicable access license found.

\section{Share Your Story}

The Harvard community has made this article openly available.

Please share how this access benefits you. Submit a story.

Accessibility 
The Contribution of National Income Inequality to Regional Economic Divergence

\author{
Robert Manduca
}

After more than a century of convergence, the economic fortunes of rich and poor regions of the United States have diverged dramatically over the last 40 years. Roughly a third of the US population now lives in metropolitan areas that are substantially richer or poorer than the nation as a whole, almost three times the share in 1980. In this paper I use counterfactual simulations based on Census microdata to understand the dynamics of regional divergence. I first show that regional divergence has primarily resulted from the richest people and places pulling away from the rest of the country. I then estimate the relative contributions to regional divergence of two major socioeconomic trends of recent decades: the sorting of people across metro areas by income level and the national rise in income inequality. I show that the national rise in income inequality is sufficient on its own to account for more than half of the observed divergence across regions, while income sorting on its own accounts for less than a quarter. The major driver of regional economic divergence is national-level income dispersion that has exacerbated preexisting spatial inequalities. 
Regions of the United States are pulling apart. In 1980, less than $12 \%$ of the US population lived in metropolitan areas whose mean family incomes were at least $20 \%$ larger or smaller than the national average. By 2013, that share had climbed above $30 \%$, almost tripling in 30 years. This divergence was a reversal after more than a century during which the poorest parts of the country caught up economically to the rest (Amos 2014; Ganong and Shoag 2017). As cities like San Francisco, New York City, and Washington, DC pull away from the rest of the country, it becomes increasingly difficult to speak of one American standard of living.

Regional income divergence is a major economic and social challenge for the United States. It makes formulating federal economic policy difficult, since one federal budget and interest rate must meet the needs of rich and poor regions simultaneously (Schleicher 2017). It may also contribute to the country's large regional variation in upward mobility rates (Chetty et al. 2014), since the economic conditions of children's communities strongly affect their prospects in life (Sharkey 2013; Sharkey and Faber 2014). More fundamentally, divergence contributes to a lack of social and political cohesion, as the material interests of different parts of the country diverge and their residents come to see themselves as having less and less in common (Beramendi 2007, 2012).

The aim of this paper is to determine the nature of the processes driving regional income divergence. Most scholarship on regional divergence, rooted in the traditions of economic geography and urban economics, has emphasized the ability of some places to outperform others in a global economic competition, one exacerbated by federal policy changes in the late twentieth century (Harvey 1989; Rodríguez-Pose and Gill 2004). Some accounts stress the ability of certain places to attract talented individuals based on lifestyle or economic opportunity (Florida 2002, 2005; Moretti 2012), while others describe how some communities are better able to come together to solve their collective problems, resulting in not just more consistent but also 
more equitable growth (Benner and Pastor 2012, 2015; Storper et al. 2015). In both accounts the result is the stratification of metro areas by income, as the thriving and struggling portions of the modern economy are sorted into increasingly disjoint sets of cities.

In this paper I draw on insights from urban and rural sociology to explore an alternative explanation: that regional divergence largely results from the spatially disparate effects of a single national-level trend. As cities were becoming more stratified by education and income after 1980, the distribution of economic resources was also becoming much more skewed. The share of national pre-tax income going to the richest $1 \%$ of Americans has almost doubled since 1975, while the incomes of the poorer half of the population have hardly budged in real terms (Piketty, Saez, and Zucman 2017).

Prevailing explanations for rising inequality attribute it to national or global changes in technology (e.g. Goldin and Katz 2010) and institutions (e.g. Hacker and Pierson 2010). These changes are typically described in aspatial terms. But regions of the United States have long been stratified economically (Lobao 2016; Tickamyer and Patel-Campillo 2016; Weber and Miller 2017). Because different income groups are unevenly distributed across the country, national changes will have spatially uneven effects. Like a wave that washes over an uneven landscape, leaving behind deep pools in some areas and shallow puddles in others, the same macro-level social trend can have very different impacts on different areas depending on how people are distributed across space.

Previous research has documented this general phenomenon in settings including the concentration of poverty (Massey 1990), incarceration (Sampson and Loeffler 2010), and deindustrialization (Autor, Dorn, and Hanson 2013). The intuition behind it was perhaps best captured by Massey (1990), who used simulations to show that the combination of racial and class segregation would concentrate the effects of a national economic downturn into specific 
neighborhoods. He showed that in a hypothetical city completely segregated by race and class, a 2.5 percentage point increase in the overall poverty rate would coincide with a 20 percentage point increase in the poverty rate of poor black neighborhoods. When places are highly stratified, small macro shifts can have immense local consequences.

In the spirit of Massey, this paper uses simulations to investigate the relative importance of income sorting and income inequality as drivers of regional economic divergence. After documenting the extent to which regional disparities have widened over the past 40 years, I use counterfactual simulations to show that this divergence is almost entirely driven by the richest people and places: there has been very little regional divergence, at least as typically measured, among the poorest $90 \%$ of the population. Further simulations show that regional divergence is primarily attributable to the national rise in income inequality. If income inequality had remained constant at 1980 levels, the observed income sorting would have resulted in just 23 percent as much divergence as actually occurred. In contrast, even if there had been no income sorting whatsoever, growth in income inequality would have produced 53 percent of the observed divergence on its own. Income sorting has played a role in driving regional divergence, but income inequality has played a larger one.

More broadly, this paper highlights how spatial inequality of any type can exacerbate itself. The presence of some initial amount of inequality across geographic areas will make those areas differentially susceptible to macro trends in ways that will often cause their fortunes to further diverge. This dynamic is not unique to space: it can occur in any instance where people are sorted unevenly across units - that is, in any social structure with a strong correlation between graduated and nominal parameters (Blau 1974, 1977). Once that correlation is established, the exacerbation of inequality along the graduated parameter will further increase the distance between nominal groups. The spatial implications of this are particularly 
counterintuitive, because it means that changes in spatial patterns do not have to be driven by an explicitly geographical process. Since all social processes are spatially situated, even seemingly aspatial developments will often have distinct spatial profiles.

\section{PREVIOUS RESEARCH}

\section{Regional Divergence: Theory and US Empirical Trends}

Theorists are divided about whether regions will tend to converge or diverge economically over time (Chakravorty 2014). Neoclassical economic theory predicts that the free movement of people and capital will lead to economic convergence across regions over time (Barro and Sala-i-Martin 1992). In the absence of barriers to movement, workers and investors are expected to flock to prosperous areas, competing down wages and investment returns there while lessening competition in the places they leave. This migration is predicted to continue until income or utility is even across space (Glaeser and Gottlieb 2009).

Other theorists argue that regions will economically diverge over time unless this tendency is explicitly countered, as initial advantages of location and happenstance build on themselves and create economies of agglomeration and scale that let a few lucky regions pull further and further away from the rest (Hirschman 1958; Myrdal 1957). Initially dominant regions may also use their political and economic power to exploit more peripheral regions, entrenching uneven development (Chakravorty 2014; Lipton 1977).

The history of the United States has encompassed prolonged periods of both convergence and divergence. From the late 1800 s until the 1980 s, there was substantial economic convergence between regions of the country, with initially poor states growing on average about two percentage points per year faster than initially rich ones (Barro and Sala-i-Martin 1992, 1992). Since the 1980s regional convergence has stalled, with little correlation between initial 
income and subsequent growth (Ganong and Shoag 2017). The total amount of cross-sectional variation across states began increasing in the late 1970s (Amos 1989; Fan and Casetti 1994).

Given that both convergence and divergence have occurred in the historical experience of the United States, the question for researchers is what forces explain the reversal from convergence to divergence over the last 40 years.

Previous explanations for the current round of regional divergence: individual sorting, community efficacy, and federal policy devolution

The regional divergence of the last 40 years has attracted renewed scholarly interest since the 2016 presidential election, particularly from scholars in regional science, urban economics, and economic geography (Storper 2018). Although they differ in their specifics, most of these accounts fundamentally portray regional divergence as a stratification process in which high- and low-income residents are increasingly found in different cities from one another. Some accounts focus on the location decisions of individuals, arguing that increased sorting of people across regions by human capital or income is the primary reason certain cities have pulled away from the pack (Ganong and Shoag 2017; Moretti 2012). Other accounts stress community-level factors, arguing that some regions have been able to succeed because they have strong social ties and the capacity to solve collective problems (Storper et al. 2015; Benner and Pastor 2015). Finally, a number of accounts have pointed out that the consequences of regional stratification have increased, because changes to national economic policy have raised the stakes of economic competition between regions (Harvey 1989; Rodríguez-Pose and Gill 2004).

Explanations at the individual level have emphasized the increasing geographical concentration of college-educated workers. Beginning around 1980, cities began to polarize in their educational profiles. In this "Great Divergence" (Moretti 2012), cities that already had large 
numbers of highly educated workers attracted or trained still more, while those that had fewer to start with failed to keep up (Berry and Glaeser 2005; Giannone 2017). Many rural towns experienced a brain drain as their brightest students left, rarely to return (Carr and Kefalas 2009).

One set of explanations for this concentration focuses on the attraction of skilled workers to certain places. Some researchers argue that the concentration is driven by labor demand (Diamond 2016; Storper and Scott 2009), while others emphasize the role of lifestyle considerations, particularly for the most well-compensated individuals (Clark et al. 2002; Dahl and Sorenson 2010; Florida 2002). Further accounts highlight the role of networks and social norms that funnel elite graduates specifically to certain jobs and cities (Binder, Davis and Bloome 2015; Manduca 2019).

Other explanations for increased sorting emphasize barriers that limit the ability of people to leave economically struggling areas and enter thriving ones. Limitations on housing supply, whether natural impediments like oceans and mountains or policy choices like zoning regulations, drive up the cost of living in desirable areas and make it difficult for the less affluent to live there (Ganong and Shoag 2017; Gyourko, Mayer, and Sinai 2013). There are also numerous legal barriers to interstate migration, including state occupational licensing schemes, public benefit systems, and property laws (Schleicher 2017).

The common thread of these individual-level explanations for regional divergence is the geographic sorting of people by skill or income. These accounts argue that regional fortunes are diverging because high-income people increasingly live in one set of cities while low income people live in another. As this stratification has increased over time the economic prospects of these two types of cities have drifted apart.

A second thread of research emphasizes processes at the metropolitan or community level that determine whether regions succeed or fail economically. These studies focus less on the 
question of overall divergence explored in this paper and more on the related question of what regional characteristics predict economic success. Their overarching finding is that successful regions are those where diverse local actors are connected to each other in the same "epistemic community" and can collectively solve problems (Benner and Pastor 2015; Duncan 1999; Storper et al. 2015). One important finding is that at the regional level there is very little tradeoff between growth and equity: regions that grow more consistently often have more equitable outcomes (Benner and Pastor 2012, 2015).

Both individual sorting and community effectiveness are compelling as descriptions of why some regions have outperformed others economically. But they are less successful as explanations for why economic variation across regions has increased on the whole. In focusing on the process of economic competition between regions and the regional stratification it produces, they tend to downplay the historical and political processes that determine the consequences of regional stratification and create the playing field upon which regions compete.

Research in the political economy tradition describes how the conditions for the current wave of regional divergence were fostered by national policy changes in the late $20^{\text {th }}$ Century. Starting in the 1970s, the US and other developed countries shifted from more centralized economic policies that saw uneven development as a problem to be solved towards decentralized policies that encouraged entrepreneurial governance at the local and regional levels (Agnew 2000; Brenner 2004; Harvey 1989). In the United States, where policy was already more decentralized than in most European countries, this took the form of the "New Federalism" (Nixon 1969). It involved sharp reductions in funding for regional development agencies (Glasmeier and Wood 2005), declining federal fiscal transfers to local governments (Pacewicz 2016), and the increasing use of block grants to states rather than the national administration of welfare programs (Schram and Soss 1998; Powers 2000). At the same time, financial 
deregulation and declining antitrust enforcement created a wave of corporate mergers that dramatically reshaped the employment landscape in many cities (Longman 2015; Pacewicz 2015, 2016).

This federal retreat left regions on their own to compete for investment and spur economic growth. As a result, local governments became much more entrepreneurial in promoting economic development, fundamentally altering local politics (Harvey 1989; Pacewicz $2015,2016)$. But a likely consequence of this increased competition is a divergence in the fortunes of winning and losing regions (Rodríguez-Pose and Gill 2004).

Changes in federal policy since the 1970 s created room for regional fortunes to diverge from one another to a greater extent than in the mid- $20^{\text {th }}$ century. They coincided with another national trend with regional implications: rising income inequality.

\section{Rising National Income Inequality and its Implications for Regional Disparities}

The rise in income inequality is perhaps the most momentous social and economic change of the past 40 years. Since 1975 the vast majority of US economic growth has been captured by the richest people in the country, while incomes for the poorer half have stagnated. The richest $0.1 \%$ of Americans now make roughly as much each year as the poorest $50 \%$ (Piketty et al. 2017). Importantly, inequality has risen simultaneously within race, age, gender, occupation, and education groups (Bayer and Charles 2018; Kim and Sakamoto 2008; Lemieux 2006), suggesting that it is best understood as a macro trend rather than a combination of various stratification processes.

Theories abound as to why the United States has become so unequal. The canonical explanation in the economics literature is skill-biased technological change, which in its most common form posits that technologies developed in recent decades have increased the demand 
for college-educated workers (Autor 2014; Goldin and Katz 2010). However, this explanation has difficulty accounting for empirical trends in earnings at different income and skill levels (Gottschalk 1997) and the demand for college-educated workers (Abel, Deitz, and Su 2014; Hecker 1992). Other explanations argue instead that rising income inequality stems from institutional changes - perhaps driven by the rise of the business lobby in the 1970s (Hacker and Pierson 2010) - that have eroded protections for workers at the bottom of the income distribution while maintaining or increasing protections for those at the top (Stiglitz 2015; Weeden and Grusky 2014). These changes include declines in the minimum wage (Lee 1999), decreasing levels of unionization (Western and Rosenfeld 2011), reductions in trade barriers (Autor, Dorn, and Hanson 2016), more widespread occupational licensing (Weeden 2002), and lower top marginal tax rates (Piketty, Saez, and Stantcheva 2014).

Most proposed explanations for the rise in income inequality operate at the national or global scale. Nonetheless, there is reason to expect that their effects will be felt differently in different places. Because people live in places, and because people are distributed unevenly across places with respect to income or any other social characteristic, changes in the distribution of income among people will necessarily change the distribution of income across places.

The phenomenon that macro-level shifts have spatially concentrated effects has been documented across a wide range of social domains. Possibly the most famous demonstration is Massey's simulation showing how segregation by race and class will magnify the effects of economic downturns, creating large increases in the poverty rates of specific neighborhoods from even relatively small national fluctuations (Massey 1990). The rise in mass incarceration since the 1970s has similarly fallen disproportionately on a few specific neighborhoods of concentrated disadvantage (Sampson and Loeffler 2010), and even on a small number of "Million Dollar Blocks"- single city blocks where more than $\$ 1$ million is spent incarcerating 
residents each year (Kurgan et al. 2012). Although the policy choices leading to rising incarceration rates were made at the national, state, or city level, the effects have been concentrated in particular neighborhoods.

At the regional level, increasing automation and trade with China are not inherently spatial processes, but their effects have been felt unevenly across the United States (Autor, Dorn, and Hanson 2013, 2016). Changes in industry market concentration have also been hypothesized to have effects that vary across regions (Longman 2015; Urzúa 2013).

There are reasons to expect that the national trend of rising income inequality has a similarly varied spatial profile. The United States has always had substantial geographic variation in income levels, even during periods of regional convergence (Lobao 2016; Tickamyer and Patel-Campillo 2016). These patterns have been extremely durable, particularly in rural areas: the US Department of Agriculture has identified more than 300 "persistently poor" rural counties, many of which have been persistently poor since at least the 1950s (Glasmeier 2002; Weber and Miller 2017; USDA Economic Research Service 2017). The US also has considerable subnational variation in the amount of local income inequality, driven by both economic structure and institutions (Peters 2013; Lobao and Hooks 2003; Moller, Alderson, and Nielsen 2009).

It would not be surprising if rising inequality at the national level interacted with this persistent economic unevenness to exacerbate regional disparities. This paper seeks to determine the relative importance of this process compared to the income sorting processes described above.

CONCEPTUAL SEPARATION OF INCOME SORTING AND INCOME INEQUALITY 
Scholars of stratification often find it helpful to analytically separate the allocation of people into jobs or positions from the assignment of reward packages to those positions (Weeden 2002). A similar distinction can be made between the allocation of ranks in the national income distribution to cities and the assignment of rewards to those ranks - that is, the level of income inequality. To illustrate how both sorting - here defined as the extent to which people at the same percentile of the national income distribution are found in the same cities as one another-and inequality can contribute to regional divergence, consider the hypothetical country shown in Figure 1. The country has two cities and a mean national income of $\$ 10$. At start, in panel A, incomes in City A are symmetrically distributed around a mean of $\$ 8$, while incomes in City B are similarly distributed around a mean of $\$ 12$.

[Figure 1 about here]

Panel B shows the income distributions of the two cities after an episode of income sorting. The overall distribution for the country has stayed the same, but people have moved such that high-income residents overwhelmingly live in City B while low-income residents now live in City A. In the language of Weeden, the allocation of positions-here ranks in the national income distribution - across cities has changed, but the income associated with each position has not. This sorting could be a result of high income people moving from City A to City B, as documented in the United States by Moretti (2012). Or it could result if City B proves increasingly superior to City A at creating and sustaining good jobs, along the lines described by Benner and Pastor $(2012,2015)$. As is clear in the graph, this sorting substantially reduces the amount of overlap in the two distributions, and decreases the amount of income inequality within 
each city. It also leads to divergence in the mean incomes of the two cities, with the mean income in City A falling to $\$ 7.40$ and the mean income in City B rising to $\$ 12.60$.

Panel C shows what would happen to the two cities with no sorting but an increase in income inequality at the national level—if the set of positions in each city does not change but the rewards at each position do. This stretching of the national income distribution is implemented by subtracting $\$ 1$ from the income of everyone in the country making less than $\$ 10$ and adding $\$ 1$ to the income of everyone earning more than $\$ 10$. The mean national income stays at $\$ 10$, but incomes are now more polarized. Here the two distributions show more overlap than in panel $\mathrm{B}$, and there is more inequality within each city, but the peaks are further apart than in either of the previous two panels. Mean incomes diverge by an amount comparable to panel B, with the mean income of City A falling to $\$ 7.50$ and that of City B rising to $\$ 12.50$. Importantly, a study that looked only at mean incomes would have difficulty distinguishing the sorting process in panel $\mathrm{B}$ from the stretching process in panel $\mathrm{C}$, even though the mechanisms underlying the two cases and the resulting city income distributions are quite different.

Of course, income sorting and income inequality can increase at the same time, with even greater effects on regional income disparities. This is shown in panel D, which implements the changes from panels B and C simultaneously. In this case, interaction between sorting and inequality creates divergence greater than in the previous two scenarios combined. Because the rich are both richer and more geographically concentrated, they pull the incomes of City B up much more than in either previous scenario. The same process happens in City A with the poor, with the result that the mean income of City A falls to $\$ 6.50$ while that of City B rises to $\$ 13.50$.

The relative importance of these two mechanisms is an empirical question that depends on the initial distribution of positions across cities and the amount of change in both the location and rewards of each position. That is the question I seek to answer here. 


\section{DATA AND METHODS}

In this paper I combine descriptive analysis of trends in various measures of regional economic divergence within the United States from 1980-2013 with counterfactual simulations to estimate the relative importance of income sorting and income inequality in driving this divergence.

\section{Unit of Analysis}

The proper unit of analysis for this study is the metropolitan area, consisting of a core city or cities and the surrounding suburbs. A metro area forms one cohesive unit with its own regional economy. An analysis conducted at the county level would be too fine-grained, since many counties consist primarily of wealthy suburbs whose incomes are generated in nearby cities. An analysis at the state level would be too coarse since it would lump together cities with very little in common, economic or otherwise (New York City and Buffalo share little except for a state government, for example). In my primary analysis I define metro areas using the 1990 Commuting Zones created by the US Department of Agriculture (Tolbert and Sizer 1996). Commuting Zones are defined as collections of counties linked by substantial flows of commuters. I use Commuting Zones rather than Metropolitan Statistical Areas because they cover rural areas in addition to urban ones, and I apply the 1990 Commuting Zones for all years of data so that the boundaries are consistent over time. My results are robust to the use of MSA definitions instead.

Data 
I use Census microdata for the 1980, 1990, and 2000 Decennial Censuses and the 20062010 and 2011-2015 American Community Surveys (which I will refer to using the middle years 2008 and 2013 respectively), provided by IPUMS (Ruggles et al. 2015). Because of nonresponse bias the Census, like other surveys, tends to underreport income among the very rich and very poor (Bollinger et al. 2014). ${ }^{1}$ However, the Census data breaks out income by person, which is necessary for my counterfactual analysis. In Appendix 1 I present trends in regional divergence using data on per capita personal income from the Bureau of Economic Analysis Regional Economic Accounts, which captures a greater share of economic activity.

\section{Construction of Regional Income Distributions}

I construct Commuting Zone income distributions using Census microdata. Publicly available microdata are not identified with the county or metro area of residence but are instead matched to County Groups in the 1980 Census and Public Use Microdata Areas (PUMAs) from the 1990 Census forward. To match these to metro areas I adopt the methodology of Dorn (2009), weighting individual Census records by the proportion of their PUMA's population that falls into a given Commuting Zone as calculated using the Missouri Census Data Center's Geographic Correspondence Engine (Missouri Census Data Center 2012). Unless otherwise stated all calculations using Commuting Zones are weighted by population in the year observed.

In my primary analysis I use family income, which reports the total before-tax income from all sources of spouses and children living under the same roof. The results are similar when using household income or adult male income. Results for adult women (and for all adults) are less consistent, likely because their labor force participation rate rose substantially but spatially unevenly over this time period. 


\section{Measure of Income Divergence}

There are two types of metric commonly used to measure the convergence and divergence of regional incomes: "sigma divergence" and "beta divergence" (Barro and Sala-iMartin 1990). Both metrics are constructed at the national level to measure whether average incomes across regions are converging or diverging over time. The more straightforward is sigma divergence, which measures cross-sectional dispersion among regions. A typical measure of sigma divergence is the population-weighted coefficient of variation of per capita income, which divides the standard deviation of per capita income across states or metros by the mean level (Amos 1989; Williamson 1965). Alternative, non-parametric measures include the interquartile range or the 10-90 range, both of which measure the difference between high and low percentiles as a percentage of the mean value.

While sigma divergence looks at the difference across regions at one point in time, beta divergence measures the extent to which poor regions catch up to rich ones over a period of years or decades. This compensates for the possibility of fluidity in the relative position of different regions, where rich regions as a category might be pulling away even as the specific regions who qualify as "rich" change over time. Because beta divergence controls for possible changes in rank, it is the most common divergence metric used in economics (Barro and Sala-iMartin 1992; Baumol 1986; Ganong and Shoag 2017). I show below (Figure 4) that regional income ranks were reasonably stable during this period, so here I use sigma divergence as my primary measure because of its greater temporal resolution. My results are robust to the choice of divergence measure, and I present results using beta divergence in Appendix 2.

In the following sections I first replicate previous work showing the marked divergence in regional incomes since 1980. I then show that most of this divergence was driven by changes 
affecting the richest families and the richest metro areas. Finally I estimate the contributions of sorting and rising income inequality using counterfactual simulations.

\section{REGIONAL INCOME DIVERGENCE, 1980-2013}

Metropolitan economic fortunes have diverged substantially since 1980. Figure 2 plots sigma divergence across Commuting Zones over time in mean and median family income for a variety of parametric and non-parametric measures (coefficient of variation, standard deviation of log income, inter-quartile range, and 90-10 range). All measures show a substantial increase in dispersion since 1980. The coefficient of variation of mean family income across Commuting Zones increased by more than $50 \%$ during this time, while that of median family income increased by $33 \%$.

[Figure 2 about here]

\section{The Geography of Income Growth}

As shown in Figure 2, the gap between the richest and poorest parts of the country is now larger than it has been in at least 40 years. But where are these fortunate and left-behind places? Figure 3 maps Commuting Zone mean family income relative to the nation in 1980 (panel A) and 2013 (panel B). In 1980, the only Commuting Zones in the top income category were Washington DC and the New Jersey suburbs of New York City. A huge swath of the country, including both cities and rural areas, had mean family incomes within $10 \%$ of the national mean, while rural areas in the South and Southwest had the lowest incomes. Some of these poor rural areas - in Appalachia, the Deep South, the Rio Grande Valley, and American Indian reservations 
in the interior West - contain areas of persistent poverty that have been long noted and studied (Tickamyer and Duncan 1990; Weber and Miller 2017).

By 2013 the situation had changed dramatically. Northern California, Minneapolis, and most of the eastern seaboard had moved into the top income category, with mean family incomes $20 \%$ greater than average. Parts of the interior West managed to keep pace with national income growth, but most other rural areas had fallen into the bottom income category.

[Figure 3 about here]

A consequence of this divergence has been the economic polarization of the country. In 1980 , just $7.4 \%$ of the US population lived in Commuting Zones with mean family incomes below $80 \%$ of the national average. By 2013 that share had increased to $15.7 \%$, more than doubling. On the other extreme, the share of the population living in metros more than $20 \%$ richer than average rose from $4.3 \%$ to $15.6 \%$. In total, the fraction of Americans living in especially rich or especially poor metros almost tripled, from $11.7 \%$ to $31.3 \%$. This divergence is comparable to the concurrent polarization of residents into rich and poor neighborhoods within metro areas (Reardon and Bischoff 2016).

\section{REGIONAL DIVERGENCE AND THE TOP OF THE INCOME DISTRIBUTION}

Regional divergence could be caused by rich parts of the country pulling ahead over the last 40 years, leaving the rest of the country behind. Alternatively, poor places could have gotten poorer relative to the rest of the nation than they already were. Or the entire distribution could be stretching out without a disproportionate effect in any one part. At the individual level, 
divergence could result from changes in the geographic distribution and earnings of the rich, those of the poor, or some combination.

\section{Rich Regions Drive Divergence}

Figure 4 shows that rich metro areas are the primary drivers of divergence. It plots mean family income as a percentage of the national mean for each Commuting Zone in 1980 and 2013. The Commuting Zones above the dotted line got richer relative to the nation during this period while those below the dotted line got poorer. Across most of the income distribution the dots are clustered near the line. This strong positive relationship between income in 1980 and 2013 suggests that regions have been fairly stable in income rank on the whole, although individual Commuting Zones have moved up (e.g. Philadelphia) or down (Detroit or Miami). But the relationship breaks down for the richest Commuting Zones: probably the most striking feature of the graph is the cluster of large metro areas well above the dotted line in the top-right portion of the graph. These places_-Boston, New York, San Francisco, and Washington DC—were already richer than average in 1980, but since then they have surged further ahead.

[Figure 4 about here]

\section{Rich People Drive Divergence}

In addition to the question of which metro areas are driving divergence, there is the question of which types of people are doing so. Rising average incomes in rich regions could be due to changes among their high-income populations - either increasing incomes among those who already live there or a net movement of high-income people into the region. Alternately, they could be due to changes among poor and middle class residents, again either changes to the 
incomes of those who continue living in the area or a net movement of lower income people out of the region.

To estimate the extent to which regional divergence is being driven by individuals at the top of the income distribution, as opposed to the poor or middle class, I re-compute divergence measures in the Census data after removing the highest income families in the country. Trends in the coefficient of variation of mean family income are shown in Figure 5. Top earners drive a huge portion of the overall variation in regional mean incomes: the increase in dispersion among the bottom $90 \%$ of families is just a quarter as large as the increase across the entire distribution. Even just removing the top 1\% shrinks the amount of divergence since 1980 by about half.

[Figure 5 about here]

\section{REGIONAL INCOME DIVERGENCE AS A FUNCTION OF INCOME SORTING AND}

\section{MACRO-LEVEL INCOME INEQUALITY}

I now turn to identifying the relative importance of income sorting and income inequality in driving regional divergence. I first use several direct measures of income sorting to show that the amount of income sorting across metro areas has not grown nearly as much as regional incomes have diverged. I then conduct simulations to isolate and quantify the independent contributions of increased sorting and increased inequality to regional divergence.

\section{Direct Measures of Income Sorting}

I consider three direct measures of income sorting. The first is the proportion of total national variation in family incomes that is across Commuting Zones. If income sorting had gone 
up, we would expect this proportion to increase. The second measure I consider is the income segregation across Commuting Zones as calculated by Reardon and Bischoff's rank order information theory measure $H$ (Reardon and Bischoff 2011). Finally, I calculate Zhou's $S$, a measure of the extent to which categorical groups such as races, genders, or occupations are stratified along a continuous spectrum such as income (Zhou 2012). Because $S$ is too computationally intensive to calculate for the entire sample at once, I take the mean of its value computed on 10 random draws of 100,000 observations in each year, producing an estimate of Commuting Zone income stratification.

Trends in all three measures are consistent: income sorting across Commuting Zones increased substantially in the $1980 \mathrm{~s}$, but declined after that. None of the three measures increased by more than $7 \%$ during the period $1980-2013$, while the coefficient of variation of mean family income across Commuting Zones rose by more than half during this time. This discrepancy in growth rates suggests that income sorting has played a relatively modest role in driving regional divergence.

[Figure 6 about here]

\section{Counterfactual Simulations of Sorting and Inequality}

To directly calculate the relative importance of income sorting and income inequality in driving divergence I conduct a series of simulations where I independently vary each factor on its own. I operationalize income sorting by calculating the percentage of each Commuting Zone's families in each quantile of the national income distribution for each Census year from 1980-2013. ${ }^{3}$ The shape of the national income distribution is tracked by computing the ratio of mean income within each national quantile to the overall national mean. 
To isolate the impact of each factor I allow either the extent of income sorting or the shape of the national income distribution to evolve as it did from 1980-2013 while holding the other factor constant at 1980 levels. I then re-compute the mean income for each Commuting Zone under the hypothetical scenario. With this information I can calculate divergence measures under counterfactual scenarios where only the geographic distribution of earners or only the earnings associated with each income percentile changed. Comparing these measures to the observed trends allows me to determine the independent contributions of sorting and inequality.

Figure 7 plots the coefficient of variation of Commuting Zone mean family income over time for the various hypothetical scenarios. The dotted line verifies that if both the geographic distribution and the income levels relative to national mean income had remained constant at 1980 levels there would have been no further regional income dispersion (the slight decrease over time results from changes in weights due to Commuting Zone population change). The solid line shows the regional divergence in family incomes that actually happened. From 1980-2013 the coefficient of variation of mean family income across Commuting Zones grew from $13.0 \%$ to $20.2 \%$, an increase of $55 \%$.

[Figure 7 about here]

The dashed lines show the dispersion that would have happened under the two counterfactual scenarios. Much of the divergence in the 1980s appears to have been due to geographical sorting: keeping the 1980 income distribution but sorting people across geography as they were in 1990 results in more than half as much dispersion from 1980 to 1990 as occurred in reality. But after 1990 the importance of geographical sorting declined substantially and the role of income inequality increased. In total, about $53 \%$ of the increase in the coefficient of 
variation of Commuting Zone mean family income from 1980-2013 was due solely to increasing national inequality, about $23 \%$ was due solely to increased geographical concentration, and the remaining $24 \%$ was due to interactions between the two (specifically, the effect of rising incomes for rich families was magnified by their increased geographic concentration, as in panel D of Figure 1).

The overall finding from Figure 7-that the rise in macro-level income inequality would have resulted in substantial regional divergence without any increase in sorting, and that the reverse is less true - is robust to a variety of income measurements (household income, family income, and individual income for adult men) and measures of sigma divergence (coefficient of variation, inter-quartile range, and 10-90 range). It is also robust to controlling for changing populations by weighting observations in all years by population in 1980 or 2013 only, and to normalizing income by family or household size (which effectively counts each dollar exactly once) or square root of size (a common way to equivalize standards of living).

The maps in Figure 8 visualize the independent geographic effects of income inequality and income sorting. Panel A shows the mean family income of each Commuting Zone under the scenario where inequality is held constant, while panel B maps family income when sorting is held constant. Both scenarios fall in between the 1980 and 2013 maps from Figure 1, but panel A clearly shows less polarization than panel B, which has more Commuting Zones in both the highest and lowest income categories.

[Figure 8 about here]

DISCUSSION AND LIMITATIONS 
In this paper I have made two major contributions to knowledge of regional income divergence. First, I have shown that the observed divergence over the last 40 years has been almost entirely due to changes at the top of the metropolitan and individual income distributions. Regional variation in incomes has not changed much outside the richest $10 \%$ of families. Second, I have estimated how much divergence can be attributed to income sorting and how much to rising national income inequality. Roughly a quarter of the regional divergence of the past four decades is strictly attributable to increased income sorting of people across regions, while just over half is due to rising income inequality. The primary driver of regional divergence over the past 40 years is thus not changes in who lives where or which regions are thriving, but a national trend of increased inequality that has interacted with preexisting regional income distributions in geographically textured ways.

These findings carry important implications for studies of regional economic outcomes. First, while many previous accounts of divergence have focused on sorting by education and skill level (e.g. Giannone 2017; Moretti 2012), the outsize importance of very high income families suggests that divergence is more likely a function of people's incomes. Most of the observed divergence across regions is driven by changes among the highest-earning $10 \%$ of the population, a much more select group than all college graduates.

Second, these results suggest that the income sorting- and stratification-based explanations for regional divergence prominent in the literature may be missing a major part of the story. Figuring out what attracts high-income people to one city over another, or whether a particular region will be able to organize itself to address its collective challenges, may be important for understanding the rise and fall of individual cities, but those processes do not fully explain why rich places as a whole are now so much wealthier than the rest of the country. That development appears to result more from changes in the amount of money high-income people 
make than changes in where they live. Notably, many of the policy remedies that have been proposed to address regional divergence tackle the processes that I have labeled income sorting: reducing regulatory barriers to house construction and migration (Avent 2011; Yglesias 2012), or subsidizing employment in struggling regions (Austin, Glaeser, and Summers 2018). While these policies may be beneficial, my findings suggest that they are unlikely to close the economic gap between regions on their own.

It is important to note the limitations of this analysis. First, I am not directly commenting on the economic fortunes of any particular place. Individual cities have moved up and down the income ladder a great deal since 1980 . Boston, for instance, grew from being about $9 \%$ to $36 \%$ richer than average during my period of study, while Detroit fell from being $20 \%$ richer to $3 \%$ poorer. Other scholars have investigated what specific factors promote regional growth in both large-n analyses (e.g. Kemeny and Storper 2012; Partridge 2010) and case studies (e.g. Saxenian 1996; Storper et al. 2015). Successfully attracting and retaining skilled workers almost certainly plays a role in securing the prosperity of any one city. My results speak instead to the overall level of dispersion across metro areas - why it is that the richest cities were less than $30 \%$ richer than the country as a whole in 1980 , but are more than $50 \%$ richer today.

Second, sorting and inequality are not entirely separable as causal economic processes. Agglomeration economies, for instance, may mean that wages at the top are rising because workers are sorting by education or industry. Barriers to migration may increase overall inequality by preventing people from moving in search of higher wages (Ganong and Shoag 2017), just as rising inequality may induce sorting by pricing people out of wealthy areas (Gyourko et al. 2013). Even if sorting and inequality were fully indistinguishable causally, though, the exercise conducted here would be informative as an investigation of geographic 
scale: is the total set of economic changes driving divergence felt more through changes in the distribution of people across space or income across people? I have shown that it is the latter.

\section{CONCLUSION}

With any spatially patterned social outcome, a core question for social scientists is the scale of the driving process. Does a changing map reflect the myriad idiosyncratic decisions of individual people and organizations? Or is it a consequence of one national trend interacting with existing spatial structures? In this paper I have demonstrated that the regional income divergence the US has experienced over the last four decades largely falls into the second category. By applying insights on the interaction between spatial structure and macro-level trends developed in the study of neighborhood poverty, I have shown that the past 40 years of regional income divergence are primarily a case of national-level income dispersion exacerbating previously existing spatial inequalities. The major change in the economic geography of the US during this time was not in who lives where but in how much money they make.

A corollary to this finding is that the various potential downsides to regional divergence — macroeconomic policy challenges, political dysfunction, reduced social mobility, etc.- -are perhaps best understood as yet more malign consequences of the concentration of economic resources. The doubling of the income share going to the richest $1 \%$ is mathematically inseparable from the income stagnation that has occurred in regions where they don't happen to live. Hollowed-out towns in middle America are inextricably tied to the same institutional structures, technological changes, and rent-seeking behaviors that have enriched a small slice of the population primarily residing in a handful of major cities. 
Although my investigation has focused on space, the mechanism driving it is not inherently spatial. It generalizes to any social structure with strong with strong correlations between graduated and nominal parameters (Blau 1974, 1977). Once nominal groups-races, genders, occupations, Commuting Zones — are sorted by income or by any other graduated parameter, changes along that parameter are sufficient to affect inter-group inequality. No further group-based stratification is necessary. This dynamic appears to be important in explaining the persistence of race and gender wage gaps in the United States over the past five decades (Bayer and Charles 2018; Blau and Kahn 1996; Mandel and Semyonov 2005; Manduca 2018). Here I have demonstrated that it applies to inequalities between regions of the country as well. Like inequalities between races or genders, disparities between regions are in large part determined by the level of inequality in the nation as a whole.

On some level, the message of this study is a core claim of human geography: every social process is spatially situated. Because people are distributed unevenly across places, any process that affects some types of people more than others will have varied effects on places as well. As social scientists of all stripes increasingly recognize the importance of context and place in the phenomena they study (e.g. Logan 2012; Voss 2007), internalizing this truth will be critical. 


\section{ENDNOTES}

1. The total proportion of GDP accounted for in the Census during my sample period ranges from $77.9 \%$ in 1980 to $62.0 \%$ in 2013 .

2. Even this small increase in sorting may be inflated by bias due to the lower sampling rate of the ACS after 2000 compared to the Census long form in earlier years (Reardon et al. 2018). However, applying the bias estimation method proposed by Reardon et al. suggests that the bias at the Commuting Zone level is only about $2 \%$ as large as the bias for tracts, due to larger sample sizes.

3. In the primary analysis I use 50 quantile buckets of two percentiles each, but the results are robust to sizes ranging from 1 to 10 percentiles. I also include the ratio of mean income for a given quantile in each Commuting Zone to mean income in that quantile for the nation as a component of income sorting. 


\section{REFERENCES}

Abel, Jaison R., Richard Deitz, and Yaqin Su. 2014. "Are Recent College Graduates Finding Good Jobs?" Current Issues in Economics and Finance 20 (1).

Agnew, John. 2000. "From the Political Economy of Regions to Regional Political Economy." Progress in Human Geography 24 (1): 101-110.

Amos, Orley M. 1989. "An Inquiry into the Causes of Increasing Regional Income Inequality in The United States." The Review of Regional Studies 19 (2): 1-12.

Amos, Orley M. 2014. "Evidence of Increasing Regional Income Variation in the United States: 1969-2006." Modern Economy 5: 520-32.

Austin, Benjamin, Edward Glaeser, and Lawrence H. Summers. 2018. "Saving the Heartland: Place-Based Policies in 21st Century America." In Brookings Papers on Economic Activity. Washington DC: Brookings Institution Press.

Autor, David H. 2014. "Skills, Education, and the Rise of Earnings Inequality among the 'Other 99 Percent."” Science 344 (6186): 843-51.

Autor, David H, David Dorn, and Gordon H Hanson. 2013. "The Geography of Trade and Technology Shocks in the United States." American Economic Review 103 (3): 220-25.

Autor, David H., David Dorn, and Gordon H. Hanson. 2016. “The China Shock: Learning from Labor Market Adjustment to Large Changes in Trade.” Annual Review of Economics 8 (1): 205-40.

Avent, Ryan. 2011. The Gated City. Seattle: Amazon Digital Services.

Barro, Robert J., and Xavier Sala-i-Martin. 1990. "Economic Growth and Convergence across the United States." NBER Working Paper, no. 3419.

Barro, Robert J., and Xavier Sala-i-Martin. 1992. “Convergence.” Journal of Political Economy 100 (2): $223-251$. 
Baumol, William J. 1986. "Productivity Growth, Convergence, and Welfare: What the Long-Run Data Show." The American Economic Review 76 (5): 1072-1085.

Bayer, Patrick, and Kerwin Kofi Charles. 2018. "Divergent Paths: Structural Change, Economic Rank, and the Evolution of Black-White Earnings Differences, 1940-2014.” Quarterly Journal of Economics.

Benner, Chris, and Manuel Pastor. 2012. Just Growth: Inclusion and Prosperity in America's Metropolitan Regions. 1 edition. London: Routledge.

Benner, Chris, and Manuel Pastor. 2015. Equity, Growth, and Community: What the Nation Can Learn from America's Metro Areas. Univ of California Press.

Beramendi, Pablo. 2007. "Inequality and the Territorial Fragmentation of Solidarity." International Organization 61 (4): 783-820.

Beramendi, Pablo. 2012. The Political Geography of Inequality: Regions and Redistribution. Cambridge University Press.

Binder, Amy J., Daniel B. Davis, and Nick Bloom. 2015. "Career Funneling How Elite Students Learn to Define and Desire “"Prestigious”'Jobs." Sociology of Education 89 (1): 20-39.

Blau, Francine D., and Lawrence M. Kahn. 1996. “Wage Structure and Gender Earnings Differentials: An International Comparison." Economica 63 (250): S29-S62.

Blau, Peter M. 1974. "Presidential Address: Parameters of Social Structure.” American Sociological Review 39 (5): 615-635.

Blau, Peter M. 1977. Inequality and Heterogeneity: A Primitive Theory of Social Structure. Vol. 7. New York: Free Press.

Bollinger, Christopher R., Barry T. Hirsch, Charles M. Hokayem, and James P. Ziliak. 2014. "Trouble in the Tails: Earnings Non-Response and Response Bias across the Distribution." Paper presented at the Annual Meeting of the Society of Labor 


\section{Economists.}

http://citeseerx.ist.psu.edu/viewdoc/download?doi=10.1.1.713.9098\&rep=rep1\&type=pdf

Brenner, Neil. 2004. New State Spaces: Urban Governance and the Rescaling of Statehood.

Oxford: Oxford University Press.

Carr, Patrick J., and Maria J. Kefalas. 2009. Hollowing out the Middle: The Rural Brain Drain and What It Means for America. Boston: Beacon Press.

Chakravorty, Sanjoy. 2014. Fragments of Inequality: Social, Spatial and Evolutionary Analyses of Income Distribution. Routledge.

Chetty, Raj, Nathaniel Hendren, Patrick Kline, and Emmanuel Saez. 2014. "Where Is the Land of Opportunity? The Geography of Intergenerational Mobility in the United States." The Quarterly Journal of Economics 129 (4): 1553-1623.

Clark, Terry Nichols, Richard Lloyd, Kenneth K. Wong, and Pushpam Jain. 2002. "Amenities Drive Urban Growth.” Journal of Urban Affairs 24 (5): 493-515.

Dahl, Michael S., and Olav Sorenson. 2010. "The Social Attachment to Place.” Social Forces 89 (2): 633-658.

Diamond, Rebecca. 2016. “The Determinants and Welfare Implications of U.S. Workers' Diverging Location Choices by Skill: 1980-2000." American Economic Review 106 (3): 479-524.

Dorn, David. 2009. "Essays on Inequality, Spatial Interaction, and the Demand for Skills." University of St. Gallen.

Duncan, Cynthia M. 1999. Worlds Apart: Why Poverty Persists in Rural America. Yale University Press.

Fan, C. Cindy, and Emilio Casetti. 1994. "The Spatial and Temporal Dynamics of US Regional Income Inequality, 1950-1989.” The Annals of Regional Science 28 (2): 177-196. 
Florida, Richard. 2002. The Rise of the Creative Class. New York: Basic Books.

Florida, Richard. 2005. The Flight of the Creative Class. Harper Business New York.

Ganong, Peter, and Daniel Shoag. 2017. "Why Has Regional Income Convergence in the US Declined?" Journal of Urban Economics 102: 76-90.

Glaeser, Edward L., and Joshua D. Gottlieb. 2009. "The Wealth of Cities: Agglomeration Economies and Spatial Equilibrium in the United States." Journal of Economic Literature 47 (4): 983-1028.

Glasmeier, Amy. 2002. "One Nation, Pulling Apart: The Basis of Persistent Poverty in the USA." Progress in Human Geography 26 (2): 155-173.

Glasmeier, Amy, and Lawrence Wood. 2005. “Analysis of US Economic Development Administration Expenditure Patterns over 30 Years." Regional Studies 39 (9): 1261-1274.

Goldin, Claudia Dale, and Lawrence F. Katz. 2010. The Race between Education and Technology. Cambridge, MA: Harvard University Press.

Gottschalk, Peter. 1997. "Inequality, Income Growth, and Mobility: The Basic Facts.” The Journal of Economic Perspectives 11 (2): 21-40.

Gyourko, Joseph, Christopher J. Mayer, and Todd M. Sinai. 2013. "Superstar Cities." American Economic Journal: Economic Policy 5 (4): 167-99.

Hacker, Jacob S., and Paul Pierson. 2010. Winner-Take-All Politics. New York: Simon \& Schuster.

Harvey, David. 1989. "From Managerialism to Entrepreneurialism: The Transformation in Urban Governance in Late Capitalism.” Geografiska Annaler: Series B, Human Geography 71 (1): 3-17.

Hecker, Daniel E. 1992. "Reconciling Conflicting Data on Jobs for College Graduates." Monthly Labor Review 115 (3): 3-12. 
Hirschman, Albert O. 1958. The Strategy of Economic Development. New Haven, CT: Yale University Press.

Kemeny, Thomas, and Michael Storper. 2012. "The Sources of Urban Development: Wages, Housing, and Amenity Gaps Across American Cities.” Journal of Regional Science 52 (1): $85-108$.

Kim, ChangHwan, and Arthur Sakamoto. 2008. "The Rise of Intra-Occupational Wage Inequality in the United States, 1983 to 2002." American Sociological Review 73 (1): $129-157$.

Kurgan, Laura, Eric Cadora, David Reinfurt, Sarah Williams, and Leah Meisterlin. 2012. “Million Dollar Blocks.” Spatial Information Design Laboratory. 2012.

Lee, David S. 1999. "Wage Inequality in the United States during the 1980s: Rising Dispersion or Falling Minimum Wage?" Quarterly Journal of Economics 114 (3): 977-1023.

Lemieux, Thomas. 2006. “Increasing Residual Wage Inequality: Composition Effects, Noisy Data, or Rising Demand for Skill?” The American Economic Review 96 (3): 461-498.

Lipton, Michael. 1977. Why Poor People Stay Poor: A Study of Urban Bias in World Development. London: Temple Smith.

Lobao, Linda. 2016. “The Sociology of Subnational Development: Conceptual and Empirical Foundations." In The Sociology of Development Handbook, edited by Gregory Hooks, Shushanik Makaryan, and Paul Almeida, 265-92. Oakland, California: University of California Press.

Lobao, Linda, and Gregory Hooks. 2003. "Public Employment, Welfare Transfers, and Economic Well-Being across Local Populations: Does a Lean and Mean Government Benefit the Masses?" Social Forces 82 (2): 519-556. 
Logan, John R. 2012. "Making a Place for Space: Spatial Thinking in Social Science.” Annual Review of Sociology 38 (1): 507-24.

Longman, Phillip. 2015. "Bloom and Bust.” Washington Monthly, November 28, 2015.

Mandel, Hadas, and Moshe Semyonov. 2005. "Family Policies, Wage Structures, and Gender Gaps: Sources of Earnings Inequality in 20 Countries." American Sociological Review 70 (6): 949-67.

Manduca, Robert. 2018. "Income Inequality and the Persistence of Racial Economic Disparities." Sociological Science 5 (8): 182-205.

Manduca, Robert. 2019. "Formative and Facilitative Information as Mechanisms of Human Capital Concentration.” SocArXiv working paper.

Massey, Douglas S. 1990. “American Apartheid: Segregation and the Making of the Underclass.” American Journal of Sociology 96 (2): 329-57.

Missouri Census Data Center. 2012. MABLE/Geocorr12, Version 1.2: Geographic Correspondence Engine.

Moller, Stephanie, Arthur S. Alderson, and Francois Nielsen. 2009. "Changing Patterns of Income Inequality in US Counties, 1970-20001.” American Journal of Sociology 114 (4): 1037-1101.

Moretti, Enrico. 2012. The New Geography of Jobs. Boston: Houghton Mifflin Harcourt. Myrdal, Gunnar. 1957. Economic Theory and Under-Developed Regions. London: Duckworth. Nixon, Richard. 1969. "Richard Nixon: Address to the Nation on Domestic Programs." August 8.

Pacewicz, Josh. 2015. "Playing the Neoliberal Game: Why Community Leaders Left Party Politics to Partisan Activists." American Journal of Sociology 121 (3): 826-881. 
Pacewicz, Josh. 2016. Partisans and Partners: The Politics of the Post-Keynesian Society. University of Chicago Press.

Partridge, Mark D. 2010. "The Duelling Models: NEG vs Amenity Migration in Explaining US Engines of Growth." Papers in Regional Science 89 (3): 513-536.

Peters, David J. 2013. “American Income Inequality across Economic and Geographic Space, 1970-2010." Social Science Research 42 (6): 1490-1504.

Piketty, Thomas, Emmanuel Saez, and Stefanie Stantcheva. 2014. "Optimal Taxation of Top Labor Incomes: A Tale of Three Elasticities.” American Economic Journal: Economic Policy 6 (1): 230-71.

Piketty, Thomas, Emmanuel Saez, and Gabriel Zucman. 2017. "Distributional National Accounts: Methods and Estimates for the United States." Quarterly Journal of Economics 133 (2): 553-609.

Powers, Elizabeth T. 2000. "Block Granting Welfare: Fiscal Impact on the States." Economic Development Quarterly 14 (4): 323-39.

Reardon, Sean F., and Kendra Bischoff. 2011. "Income Inequality and Income Segregation." American Journal of Sociology 116 (4): 1092-1153.

Reardon, Sean F., and Kendra Bischoff. 2016. "The Continuing Increase in Income Segregation, 2007-2012.” Palo Alto, CA: Stanford Center for Education Policy Analysis.

Reardon, Sean F., Kendra Bischoff, Ann Owens, and Joseph B. Townsend. 2018. "Has Income Segregation Really Increased? Bias and Bias Correction in Sample-Based Segregation Estimates." Demography (online pre-release).

Rodríguez-Pose, Andrés, and Nicholas Gill. 2004. "Is There a Global Link between Regional Disparities and Devolution?" Environment and Planning A 36 (12): 2097-2117. 
Ruggles, Steven, Katie Genadek, Ronald Goeken, Josiah Grover, and Matthew Sobek. 2015. Integrated Public Use Microdata Series: Version 6.0. Minneapolis: University of Minnesota.

Sampson, Robert J., and Charles Loeffler. 2010. "Punishment's Place: The Local Concentration of Mass Incarceration.” Daedalus 139 (3): 20-31.

Saxenian, AnnaLee. 1996. Regional Advantage. Cambridge, MA: Harvard University Press.

Schleicher, David. 2017. "Stuck! The Law and Economics of Residential Stagnation.” Yale Law Journal 127 (1).

Schram, Sanford F., and Joe Soss. 1998. "Making Something out of Nothing: Welfare Reform and a New Race to the Bottom.” Publius: The Journal of Federalism 28 (3): 67-88.

Sharkey, Patrick. 2013. Stuck in Place: Urban Neighborhoods and the End of Progress toward Racial Equality. Chicago: The University of Chicago Press.

Sharkey, Patrick, and Jacob W. Faber. 2014. "Where, When, Why, and For Whom Do Residential Contexts Matter? Moving Away from the Dichotomous Understanding of Neighborhood Effects.” Annual Review of Sociology 40 (1): 559-79.

Stiglitz, Joseph E. 2015. Rewriting the Rules of the American Economy: An Agenda for Growth and Shared Prosperity. New York: W. W. Norton and Company.

Storper, Michael. 2018. "Separate Worlds? Explaining the Current Wave of Regional Economic Polarization." Journal of Economic Geography 18 (2): 247-70.

Storper, Michael, Thomas Kemeny, Naji Makarem, and Taner Osman. 2015. The Rise and Fall of Urban Economies: Lessons from San Francisco and Los Angeles. Palo Alto, CA: Stanford University Press.

Storper, Michael, and Allen J. Scott. 2009. "Rethinking Human Capital, Creativity and Urban Growth.” Journal of Economic Geography 9 (2): 147-67. 
Tickamyer, Ann R., and Cynthia M. Duncan. 1990. "Poverty and Opportunity Structure in Rural America." Annual Review of Sociology 1: 67-86.

Tickamyer, Ann R., and Anouk Patel-Campillo. 2016. "Sociological Perspectives on Uneven Development: The Making of Regions.” In The Sociology of Development Handbook, edited by Gregory Hooks, Shushanik Makaryan, and Paul Almeida, 293-310. Oakland, California: University of California Press.

Tolbert, Charles M., and Molly Sizer. 1996. "US Commuting Zones and Labor Market Areas: A 1990 Update."

Urzúa, Carlos M. 2013. “Distributive and Regional Effects of Monopoly Power.” Economía Mexicana Nueva Época 22 (2): 279-295.

USDA Economic Research Service. 2017. “Rural America at a Glance.” 182. Economic Information Bulletin.

Voss, Paul R. 2007. "Demography as a Spatial Social Science.” Population Research and Policy Review 26 (5-6): 457-476.

Weber, Bruce A., and Kathleen Miller. 2017. "Poverty in Rural America Then and Now." In Rural Poverty in the United States, edited by Ann R. Tickamyer, Jennifer Sherman, and Jennifer Warlick. Columbia University Press.

Weeden, Kim A. 2002. "Why Do Some Occupations Pay More than Others? Social Closure and Earnings Inequality in the United States." American Journal of Sociology 108 (1): 55101.

Weeden, Kim A., and David B. Grusky. 2014. "Inequality and Market Failure." American Behavioral Scientist 58 (3): 473-491.

Western, Bruce, and Jake Rosenfeld. 2011. "Unions, Norms, and the Rise in US Wage Inequality." American Sociological Review 76 (4): 513-537. 
Williamson, Jeffrey G. 1965. "Regional Inequality and the Process of National Development: A Description of the Patterns." Economic Development and Cultural Change 13 (4): 1-84. Yglesias, Matthew. 2012. The Rent Is Too Damn High: What To Do About It, And Why It Matters More Than You Think. New York: Simon \& Schuster.

Zhou, Xiang. 2012. “A Nonparametric Index of Stratification.” Sociological Methodology 42 (1): 365-89. 


\section{FIGURES}
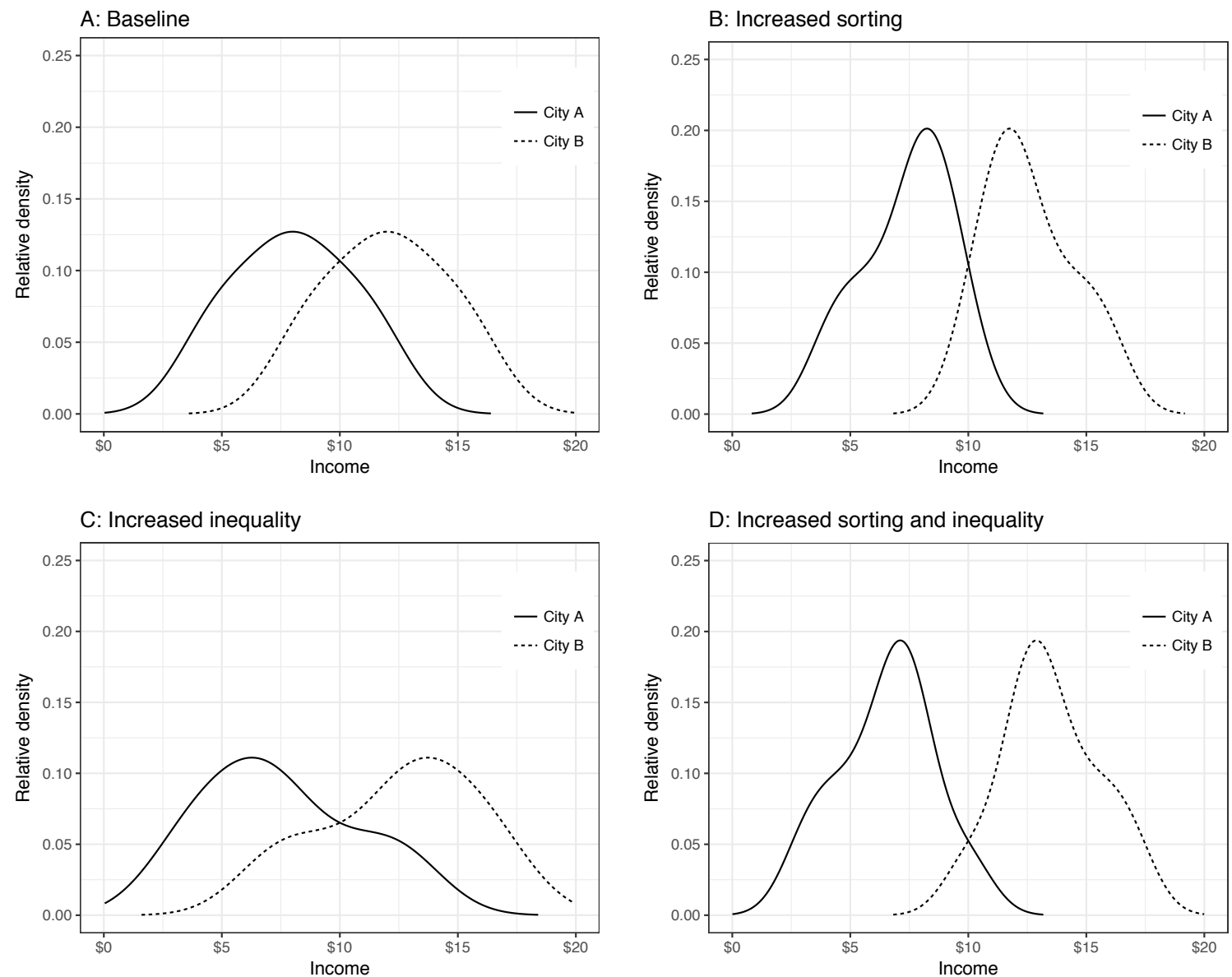

Figure 1: Hypothetical regional divergence scenarios. 


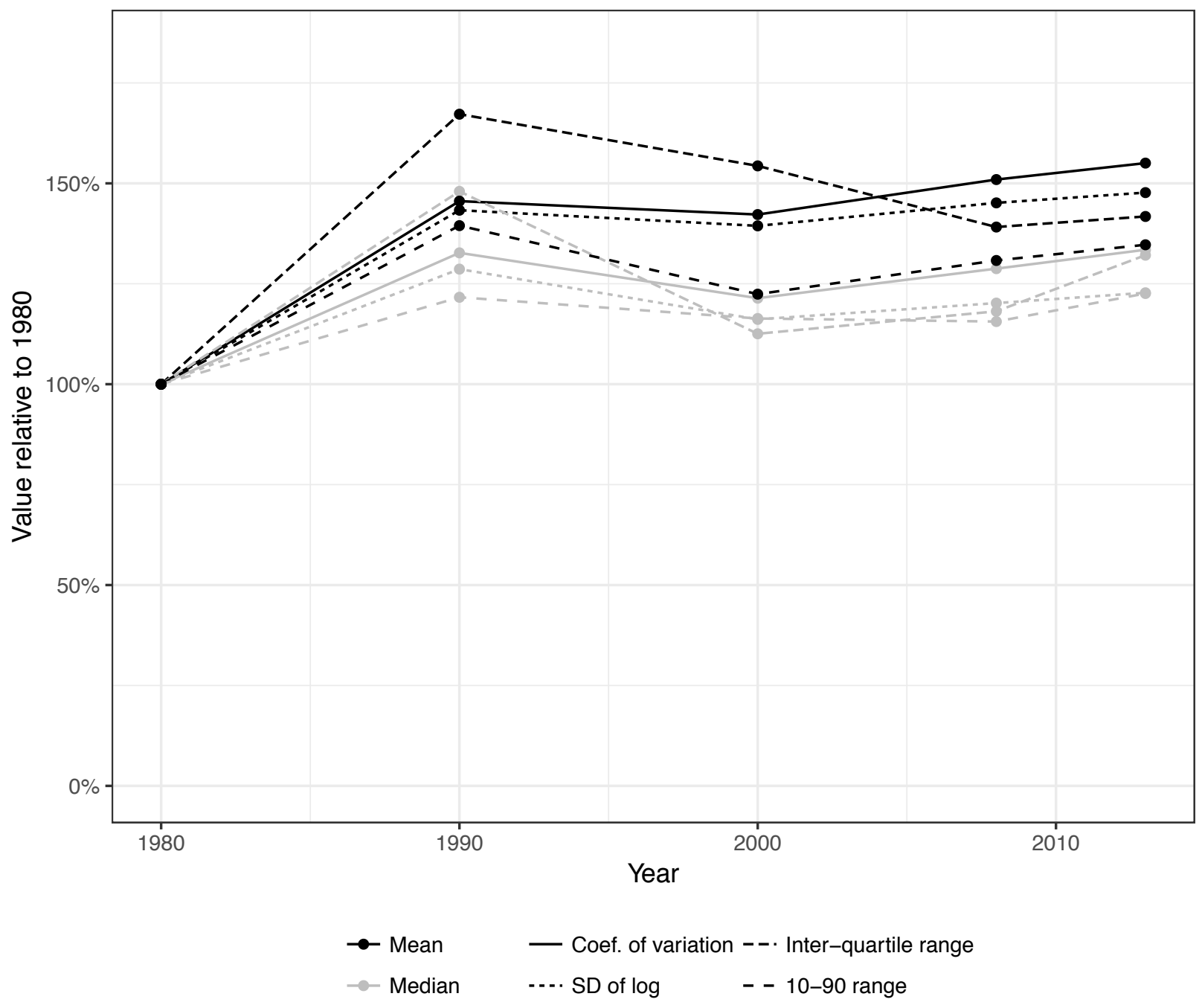

Figure 2: Sigma divergence in mean and median family income across Commuting Zones over time. 
A: 1980

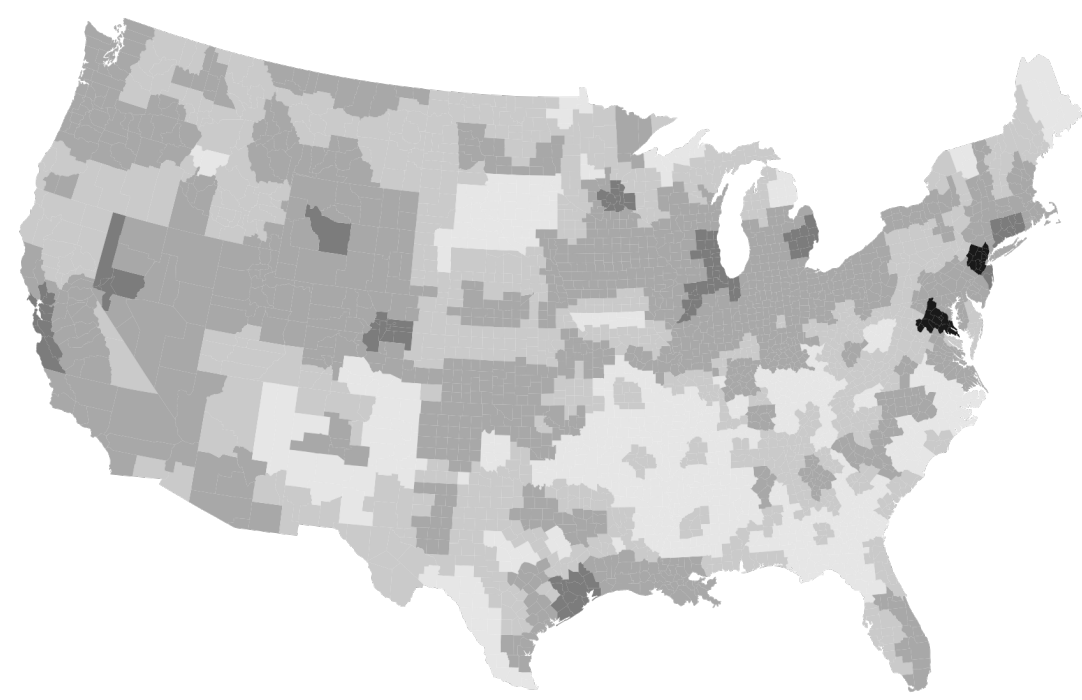

\begin{tabular}{l}
$\begin{array}{l}\text { Mean family income } \\
\text { relative to nation }\end{array} \quad<80 \%$ \\
\hline
\end{tabular}

B: 2013

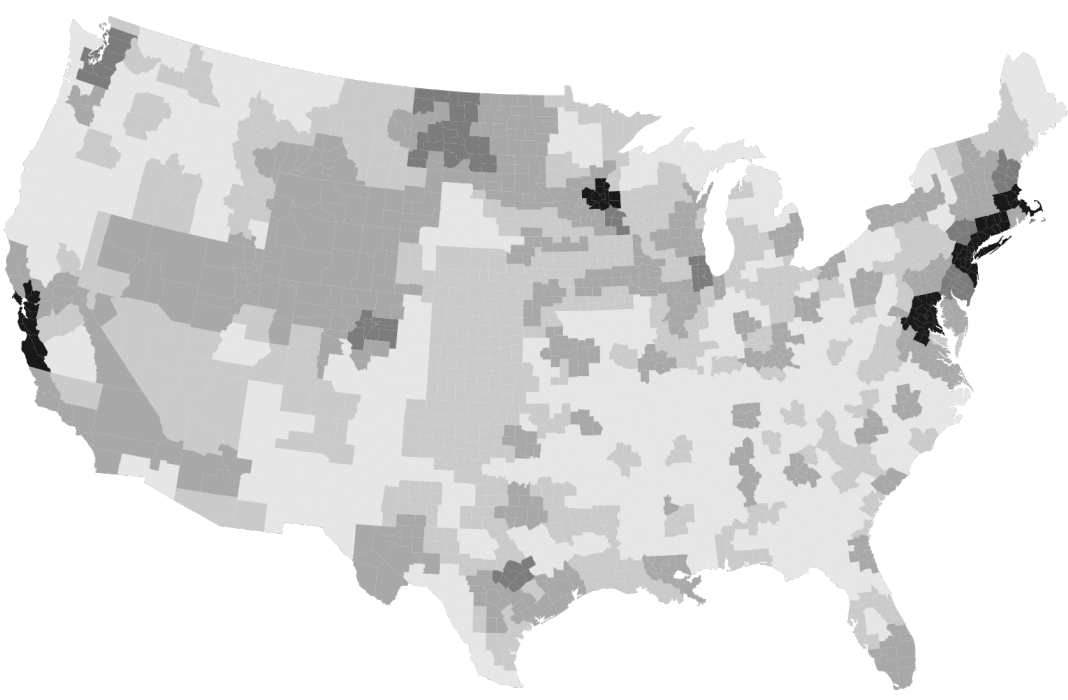

\begin{tabular}{l|l|l|l|l|l|}
$\begin{array}{l}\text { Mean family income } \\
\text { relative to nation }\end{array} \quad<80 \%$ & $80-90 \%$ & $90-110 \%$ & $110-120 \%$ & $>120 \%$
\end{tabular}

Figure 3: Maps of Commuting Zone mean famiy income. (A) 1980 and (B) 2013. 


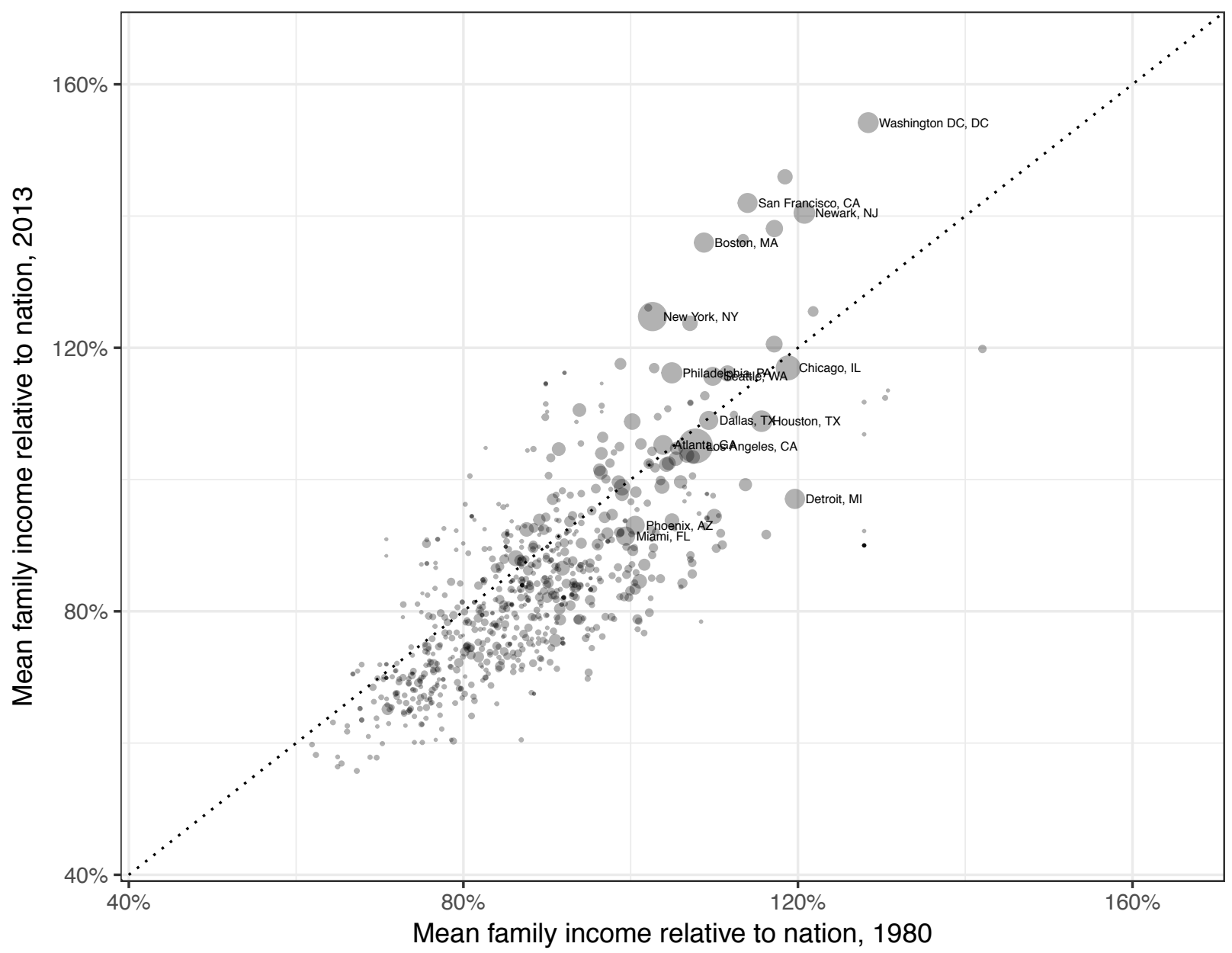

2013 Population: $\bigcirc 5,000,000 \bigcirc 10,000,000 \bigcirc 15,000,000$

Figure 4: Changes in Commuting Zone mean family income relative to the nation, 1980-2013 


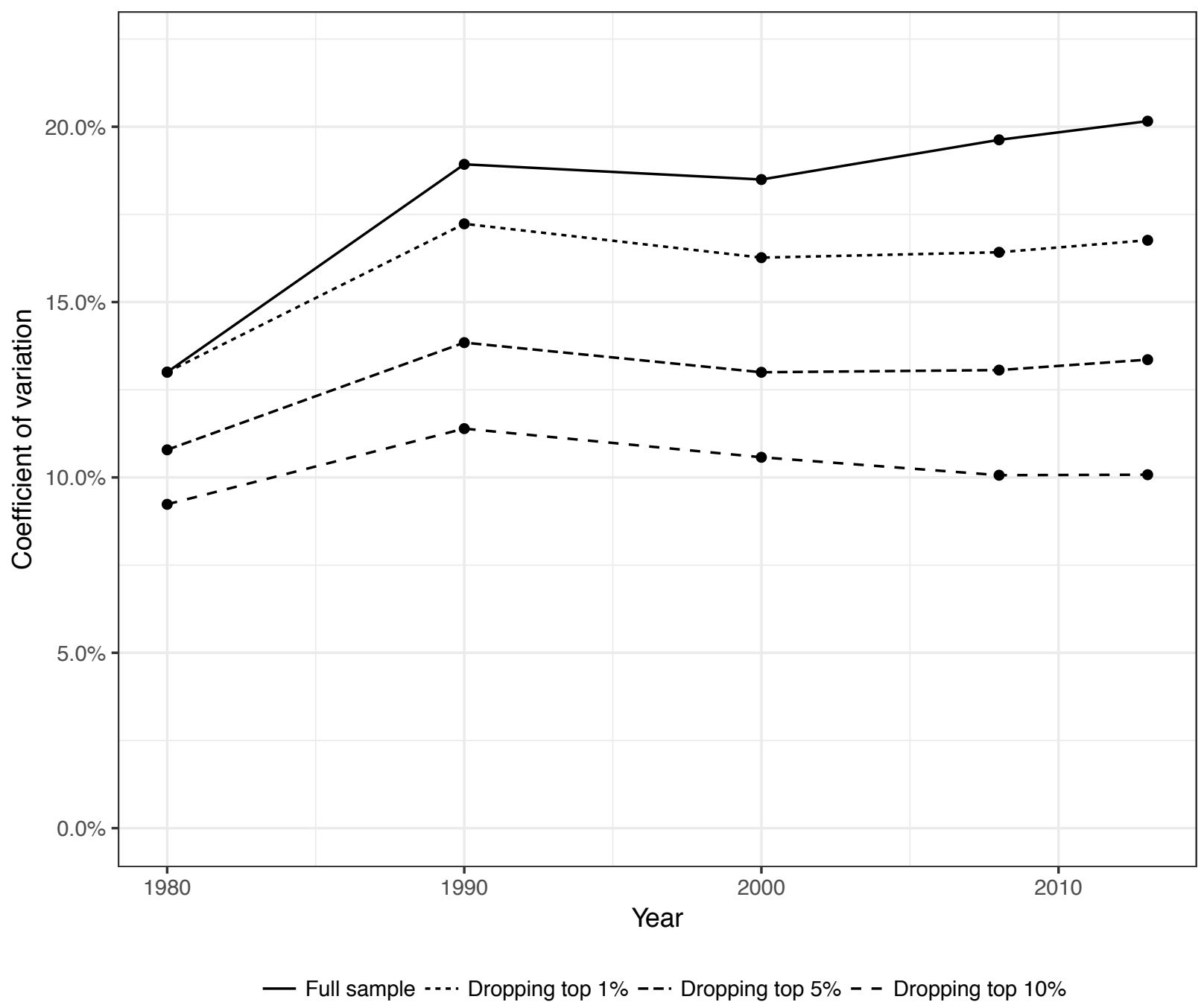

Figure 5: Counterfactual coefficient of variation of mean family income across Commuting Zones over time with various high-income groups removed. 


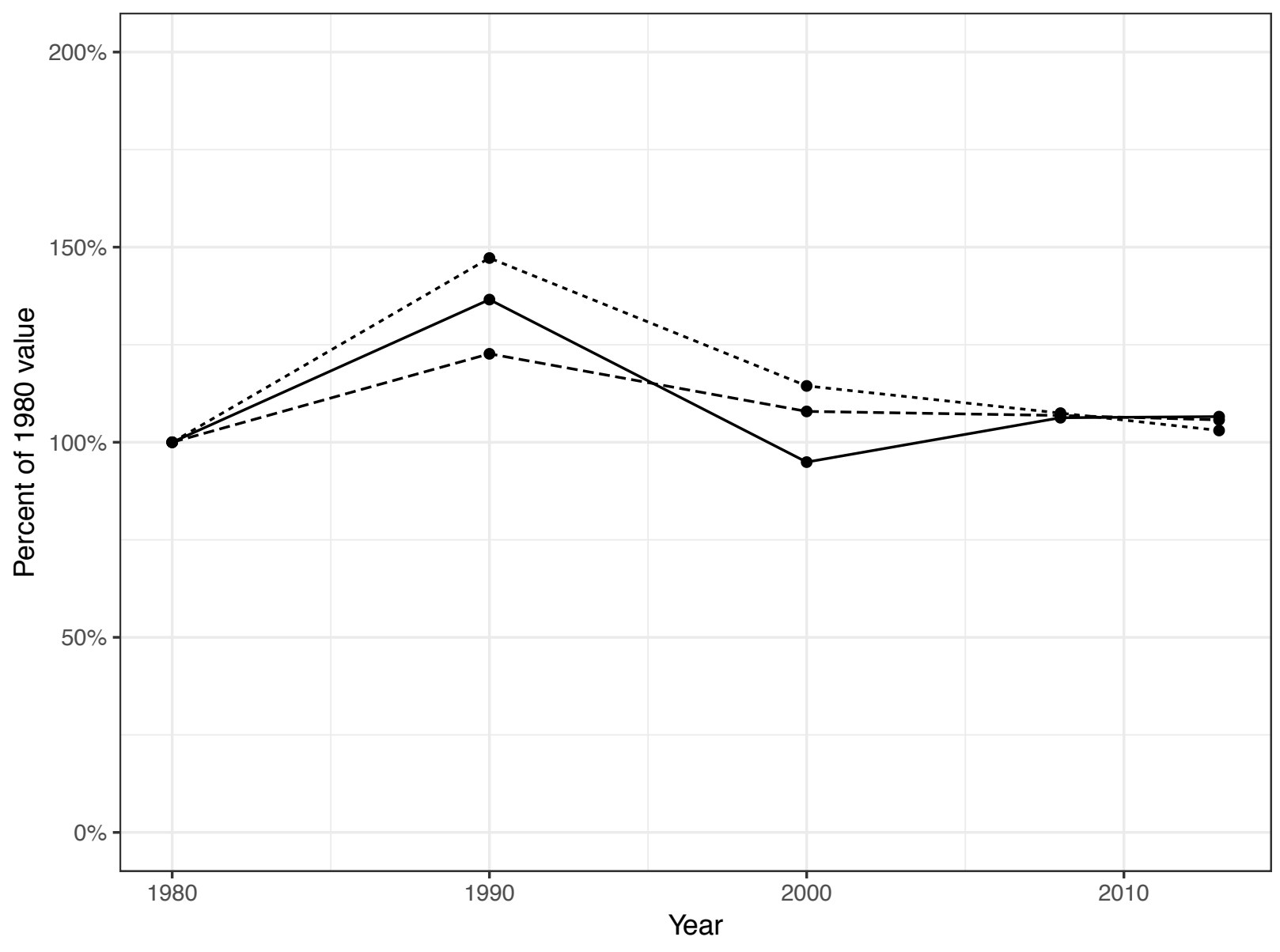
Prop. of total income variation
across Commuting Zones

_. Zhou's S (mean of 10

samples of 100,000 obs.)

Figure 6: Change over time in alternative income sorting measures. 


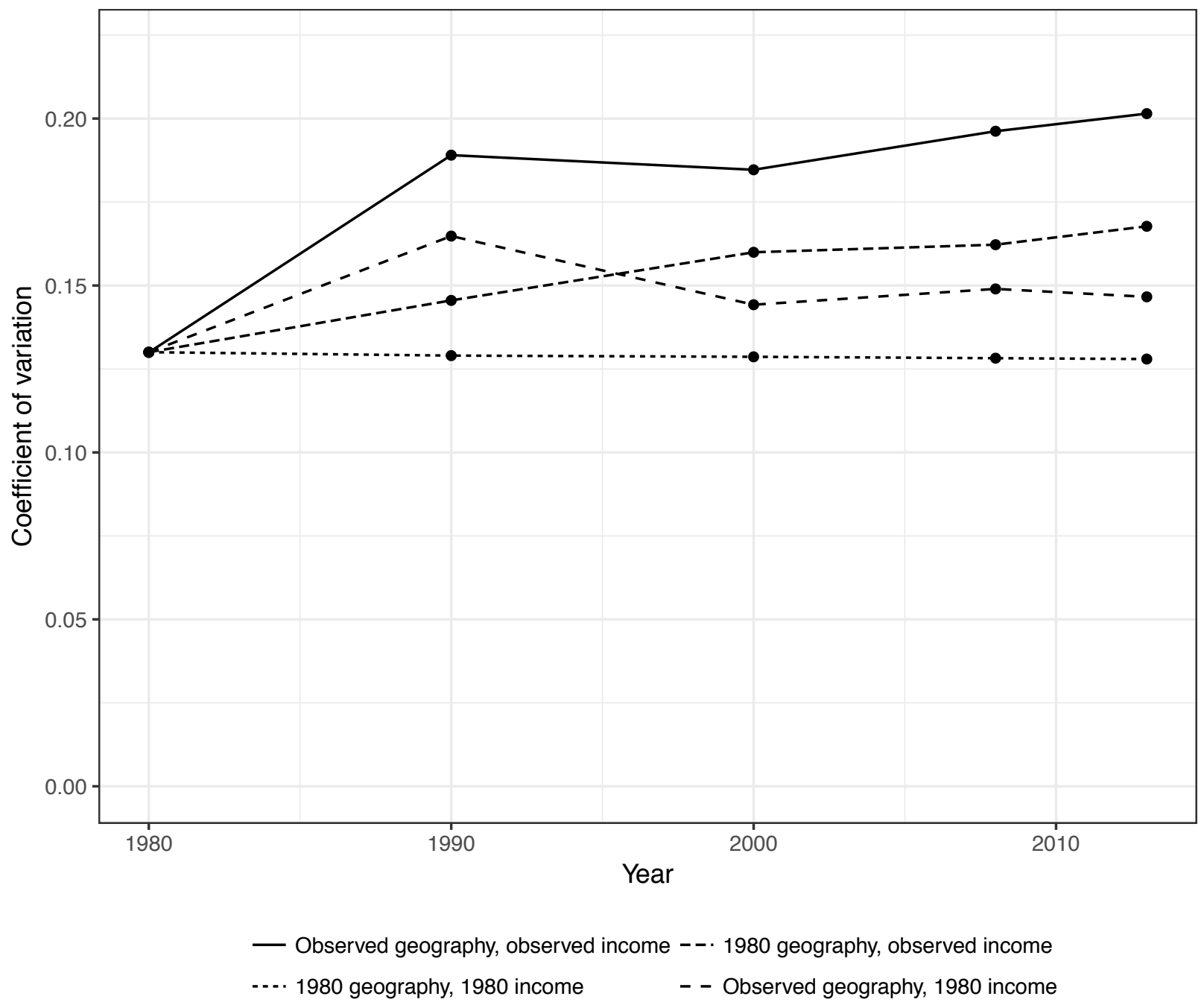

Figure 7: Counterfactual coefficient of variation of mean family income across Commuting Zones over time holding sorting and/or inequality constant at 1980 levels. 
A: 2013 sorting, 1980 inequality

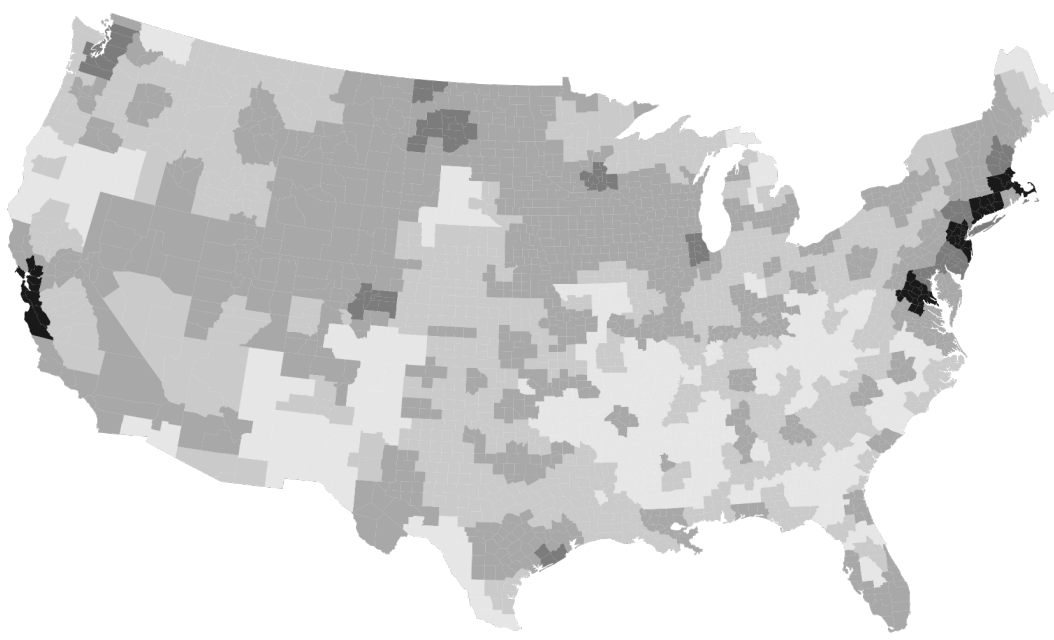

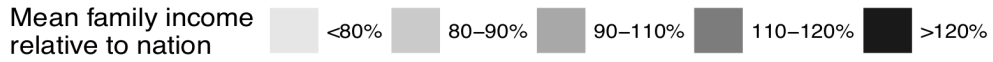

B: 1980 sorting, 2013 inequality

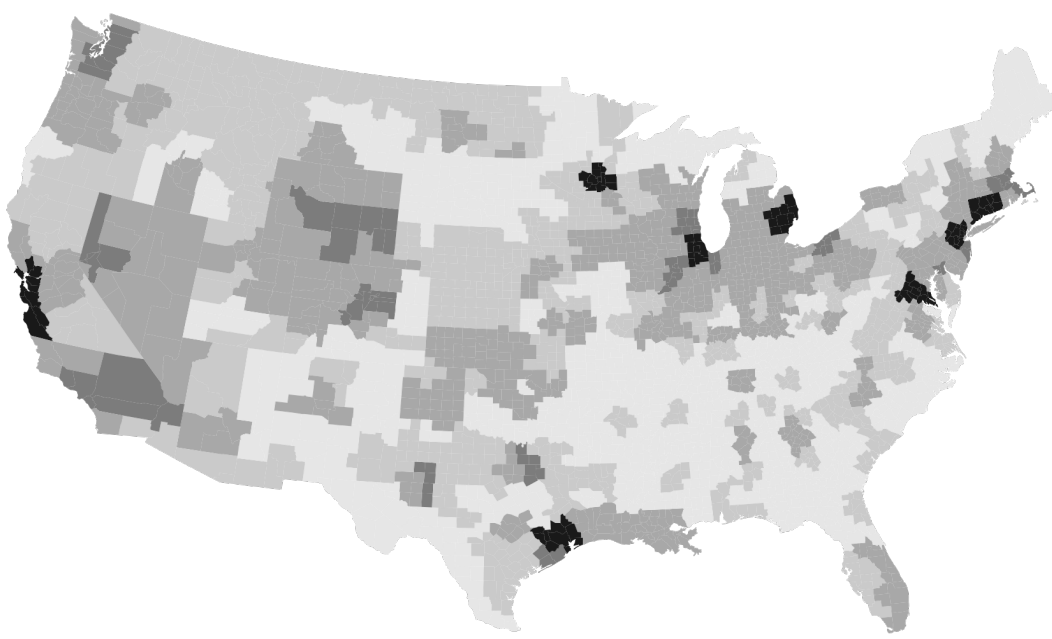

\begin{tabular}{l}
$\begin{array}{l}\text { Mean family income } \\
\text { relative to nation }\end{array} \quad<80 \%$ \\
\hline
\end{tabular}

Figure 8: Maps of counterfactual divergence scenarios. (A) Counterfactual mean family income with 2013 geographic distribution and 1980 level of income inequality. (B) Counterfactual mean family income with 1980 geographic distribution and 2013 level of income inequality. 
Online Appendix for "The Contribution of National Income Inequality to Regional Economic Divergence 


\section{APPENDIX 1: Trends in Regional Divergence Measured Using BEA Data on Commuting Zone Per Capita Personal Income}

Here I replicate my descriptive analysis of trends in regional economic divergence using data from the US Bureau of Economic Analysis Regional Economic Accounts. This data source captures a greater portion of the total economic activity in the country than the Census data that I use in my main analysis does. However, the BEA data only provide the total and mean income for each region, which makes it impossible to conduct my counterfactual analysis.

Figure A1.1, analogous to Figure 1 in the main text, shows trends in sigma divergence measures using the BEA data. As in the Census data, there has been a substantial increase in the amount of cross-sectional variation in per capita income across Commuting Zones since 1980. The coefficient of variation of per capita personal income across Commuting Zones increased by $23 \%$ from $1980-2013$.

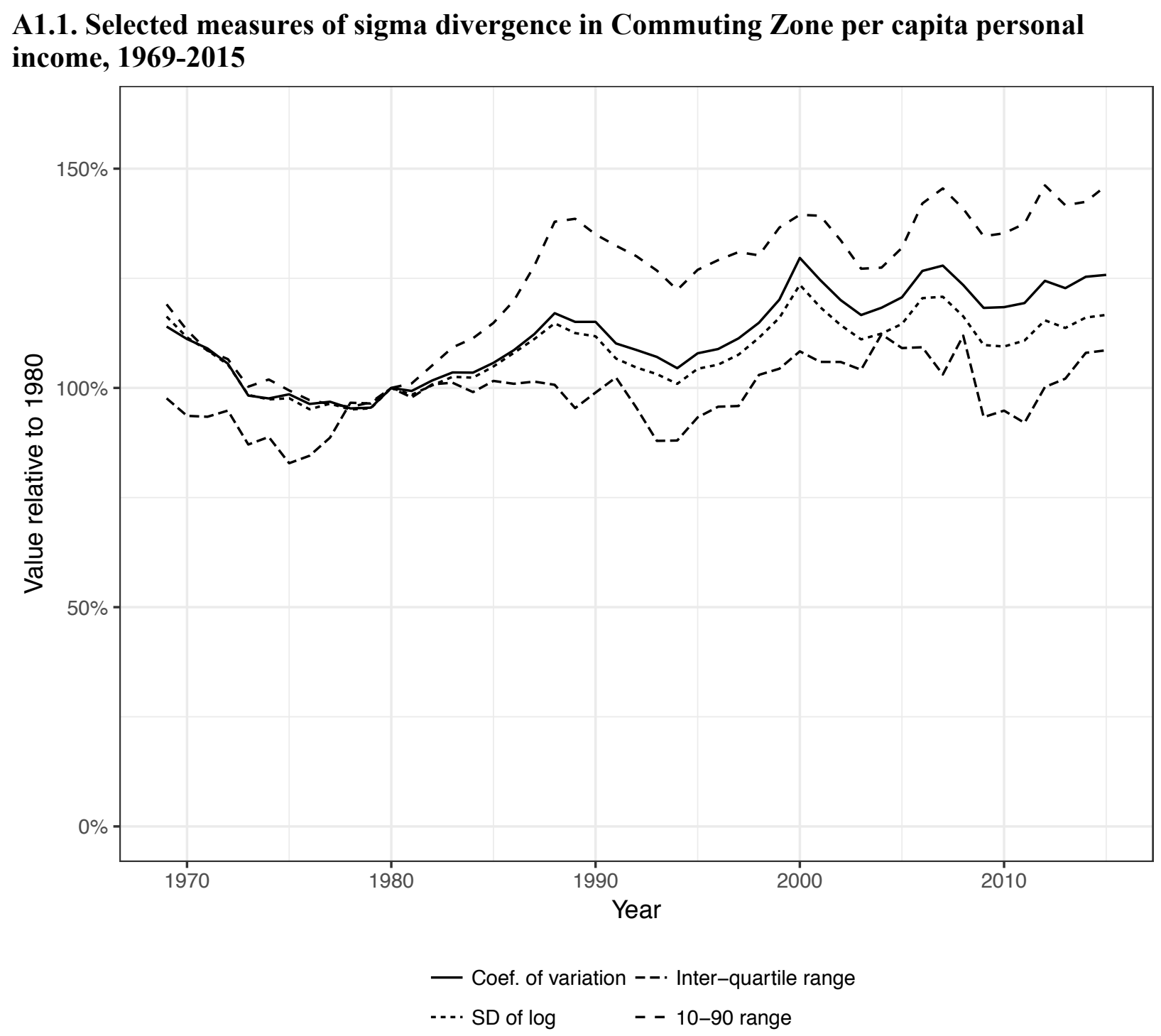


Figure A1.2 maps Commuting Zone per capita personal income as a fraction of national per capita income. Panels A and B show per capita incomes in 1980 and 2013 respectively. The divergence is similar to the maps in Figure 2 of the main text, though the trend is somewhat less visible due to the presence of rural areas in the high plains and interior west that fall into the top income category - these are either resort areas or places with high levels of mineral extraction. Rural parts of the upper Midwest and Upstate New York also show relative increases in per capita personal income during this time, which do not appear in the Census data, but these are counterweighted by relative income declines Western states.

The BEA data, which are available yearly, vary somewhat from year to year. Panels C and D of Figure A1.2 show Commuting Zone per capita personal incomes in 1975 and 2015 respectively. In these panels the economic bifurcation of the country, the hollowing out of rural areas, and the growing wealth of coastal cities is more readily apparent. This is true even though the overall level of sigma divergence as shown in Figure A1.1 was almost exactly identical in 1975 and 1980 . 
Figure A1.2. Maps of Commuting Zone per capita personal income

A. 1980

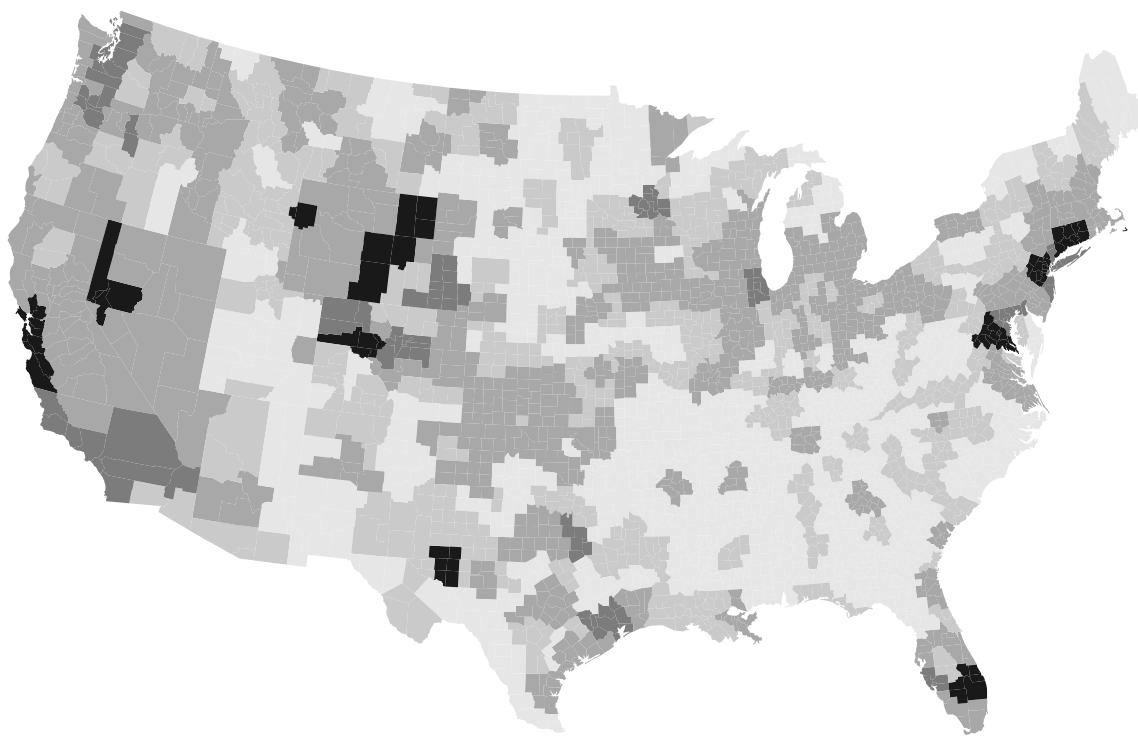

\begin{tabular}{l|l|l|l|l|l|l|}
$\begin{array}{l}\text { Per capita income } \\
\text { relative to nation }\end{array} \quad<80 \%$ & $80-90 \%$ & $90-110 \%$ & $110-120 \%$ & $>120 \%$
\end{tabular}

B. 2013

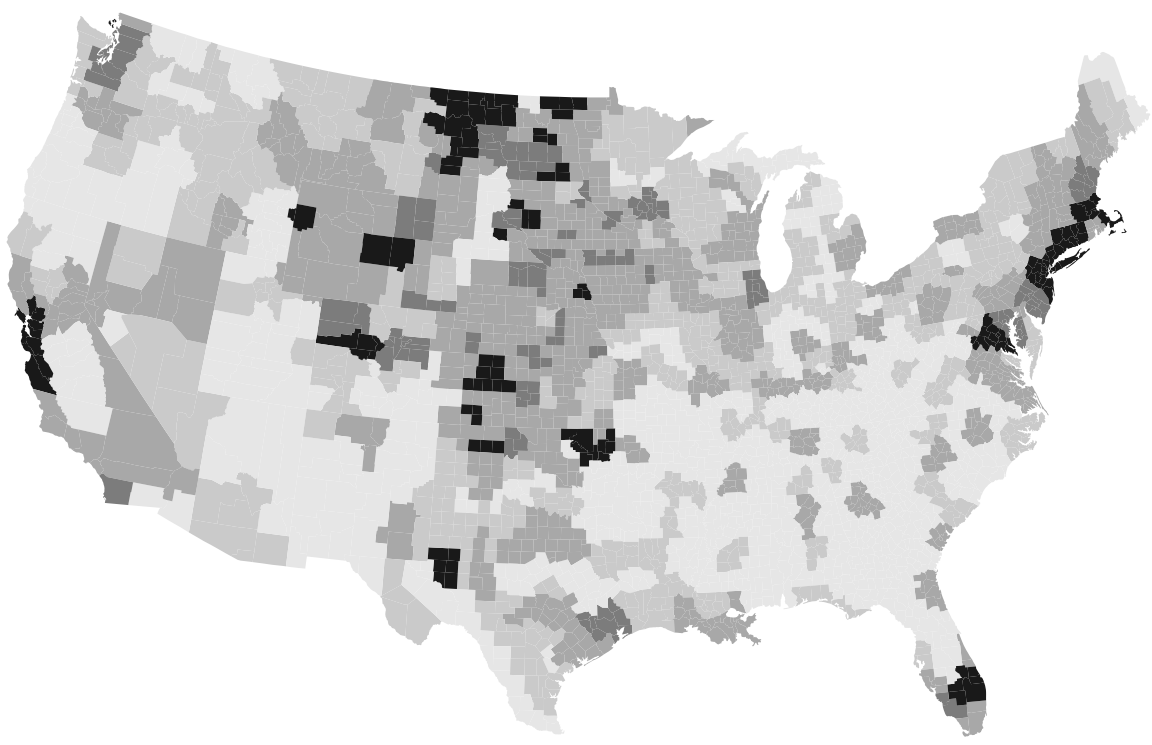

Per capita income relative to nation $<80 \%$ $80-90 \%$ $90-110 \%$ $110-120 \%$ $>120 \%$ 
C. 1975

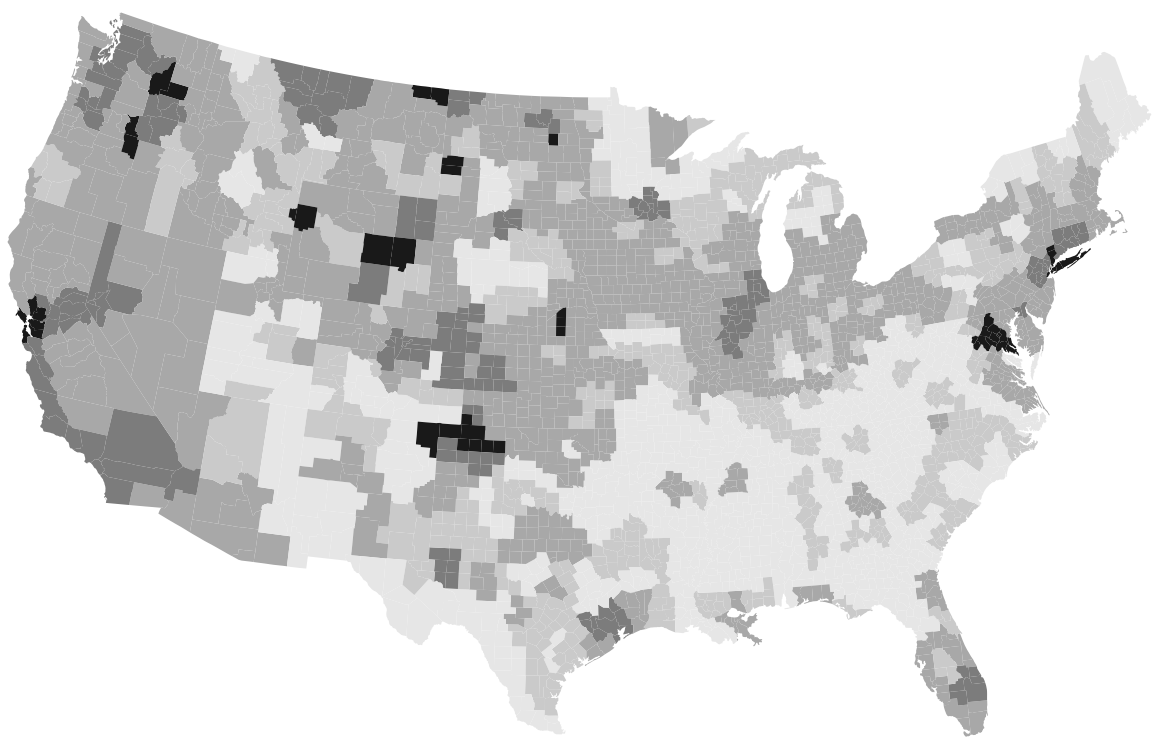

\begin{tabular}{l}
$\begin{array}{l}\text { Per capita income } \\
\text { relative to nation }\end{array} \quad<80 \%$ \\
\hline
\end{tabular}

D. 2015

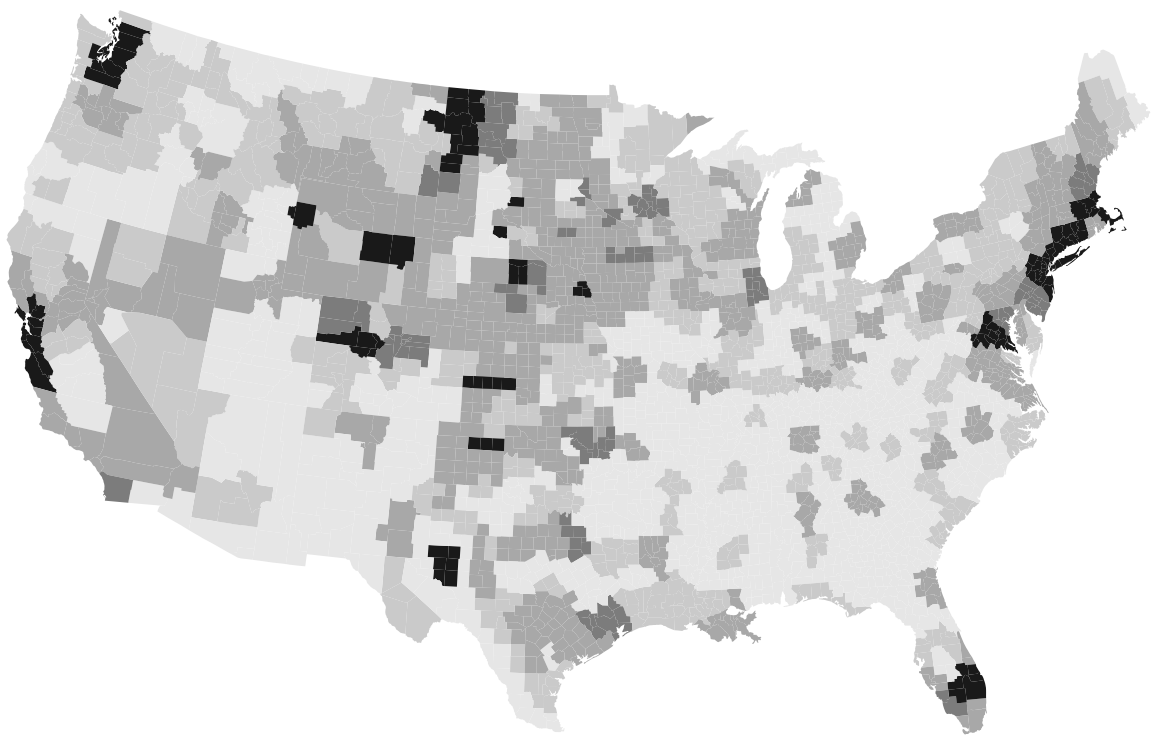

\begin{tabular}{l}
$\begin{array}{l}\text { Per capita income } \\
\text { relative to nation }\end{array} \quad<80 \%$ \\
\hline
\end{tabular} 
Figure A1.3 plots Commuting Zone per capita personal income as a fraction of national per capita personal income in 1980 and 2013. As in Figure 4 of the main text, the relationship is largely linear, with the main exceptions being several large Commuting Zones in the top right of the graph, which had above average income growth in 1980 but saw their relative position improve over the next 30 years. These include San Francisco, New York City, and Boston.

Figure A1.3. Changes in Commuting Zone per capita personal income relative to nation, 1980-2013

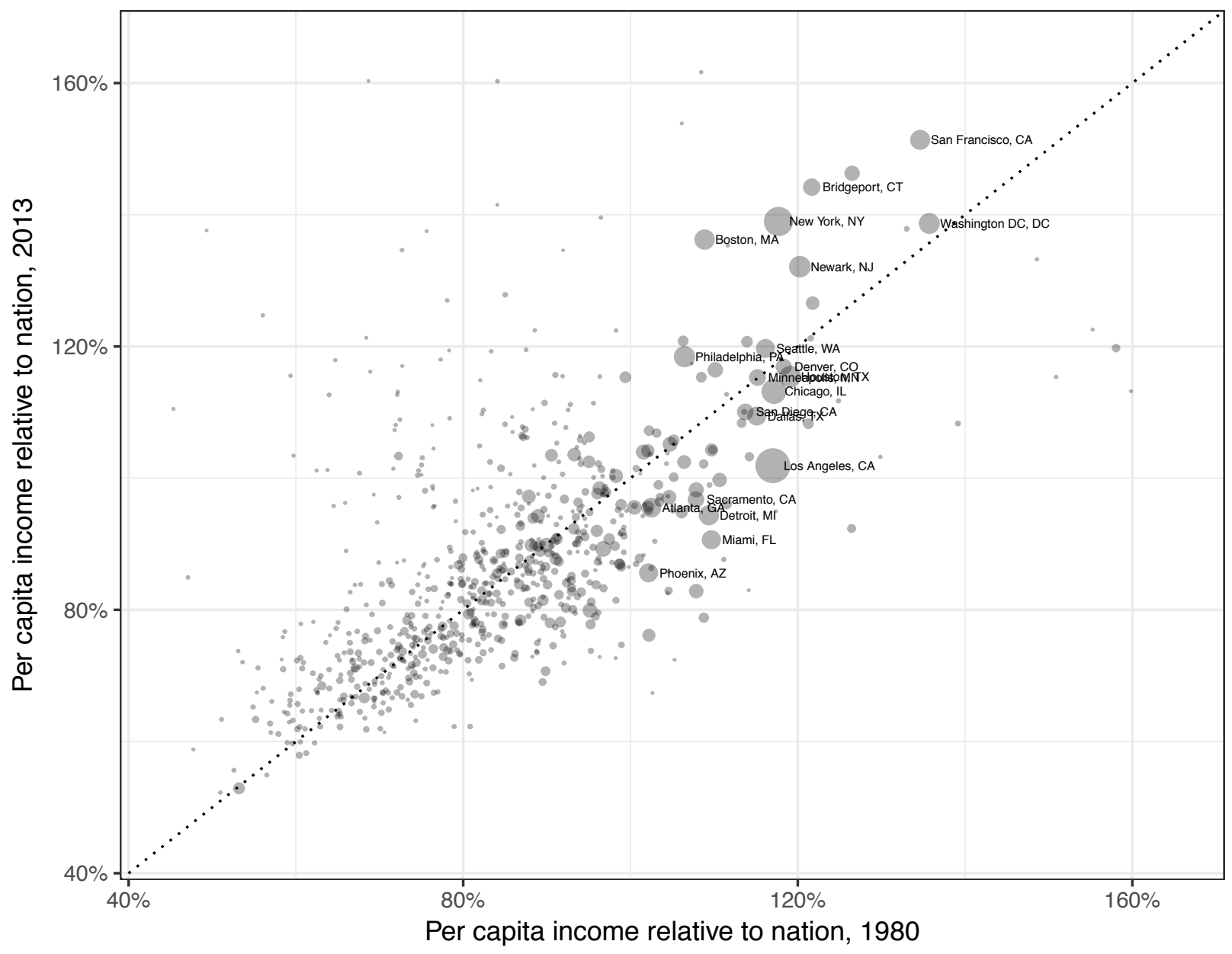

2013 Population: $\bigcirc 5,000,000 \bigcirc 10,000,000 \bigcirc 15,000,000$

Finally, Figure A1.4, which does not have an analogue in the text, highlights the role of rich metros in driving divergence by plotting the $10^{\text {th }}$ and $90^{\text {th }}$ percentiles of Commuting Zone per capita income (weighted by population) as a fraction of the median over time. While the ratio of the $10^{\text {th }}$ to $50^{\text {th }}$ percentiles is roughly constant from $1970-2015$ at $75 \%$, the ratio of the $90^{\text {th }}$ to $50^{\text {th }}$ percentiles increases dramatically during this period, from $117 \%$ in 1980 to $141 \%$ in 2013 . 
Figure A1.4. $90^{\text {th }}$ and $10^{\text {th }}$ percentiles of Commuting Zone per capita personal income as a proportion of median Commuting Zone, 1973-2015

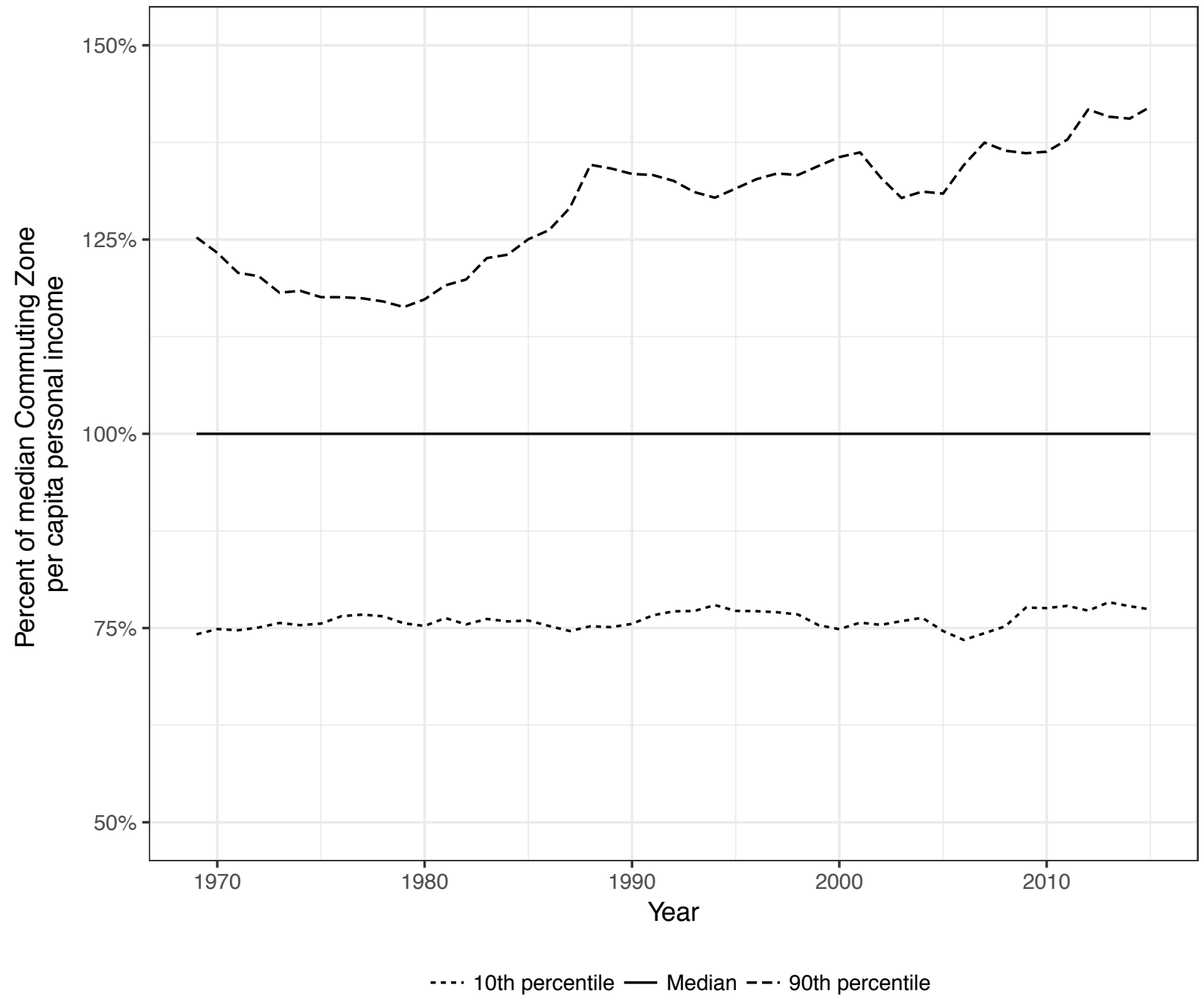




\section{APPENDIX 2: Analysis of Beta Divergence}

In this paper I have focused on sigma divergence, measuring the change in cross-sectional variation across Commuting Zones over time. An alternative approach is to measure beta divergence, the extent to which regional income growth during a period is correlated with income level at the beginning of that period. This approach has been prominent in research on divergence within economics, but suffers from a lack of temporal detail. Here I replicate my main findings using measures of beta divergence rather than sigma divergence.

\section{Observed patterns}

Figure A2.1 shows beta divergence among Commuting Zones from 1980-2013, using mean family income from the Census in Panel A and per capital personal income from the BEA data (described in Appendix 1) in Panel B. The X-axis shows income in 1980 (normalized to 2015 dollars using the CPI-U-RS) while the y-axis shows the real annualized income growth rate from 1980-2013. Each dot represents one Commuting Zone, with size proportional to 1980 population. The dashed lines are regression lines weighted by 1980 population. A positive slope on the line indicates that growth from 1980-2013 was positively correlated with income in 1980, meaning that regions diverged during this period. A negative slope indicates regional convergence - that poor regions caught up to rich ones.

Figure A2.1. Beta divergence across Commuting Zones in mean family income

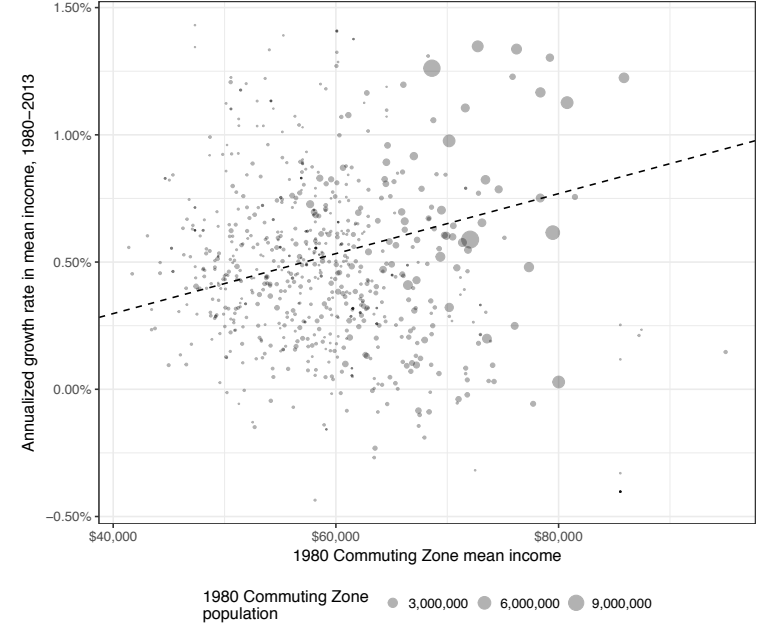

A. Mean family income, Census

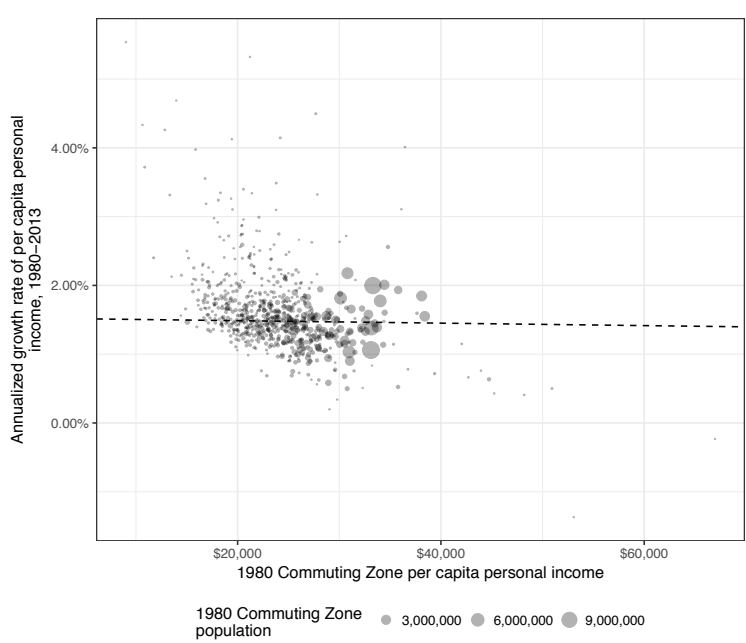

B. Per capita personal income, BEA

Panel A shows that there was divergence in mean family income across Commuting Zones from 1980-2013. Panel B shows that there time there was relatively little convergence or divergence in per capita personal income during this period. 
I next turn to the question of whether divergence is driven more by the rich surging ahead or the poor falling behind. Here I calculate beta divergence after first removing the richest $1 \%, 5 \%$, and $10 \%$ of families from the sample. The results are shown in Figure A2.2. While there was a strong trend of divergence in mean family income among the full IPUMS sample, this trend moderates substantially once the richest few percent of families are removed. Merely dropping the richest $1 \%$ of families drops the slope by more than half (panel A), while removing the top $5 \%$ of families results in a slope that is almost perfectly flat (panel B). Among the bottom $90 \%$ of families there was convergence in incomes across Commuting Zones during this time (panel C).

Figure A2.2. Simulated beta divergence in family income across Commuting Zones, 19802013 , dropping richest $1 \%(\mathrm{~A}), 5 \%(\mathrm{~B})$, and $10 \%(\mathrm{C})$ of families.

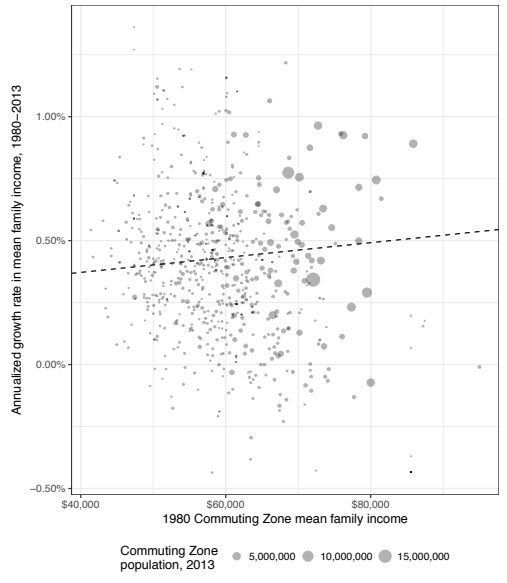

A. Richest $1 \%$ dropped

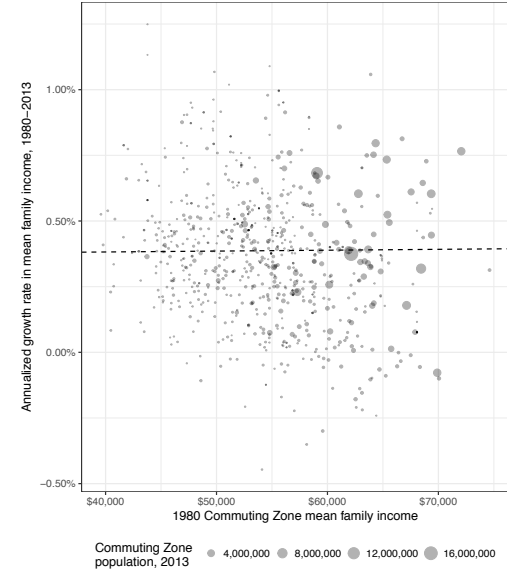

B. Richest 5\% dropped

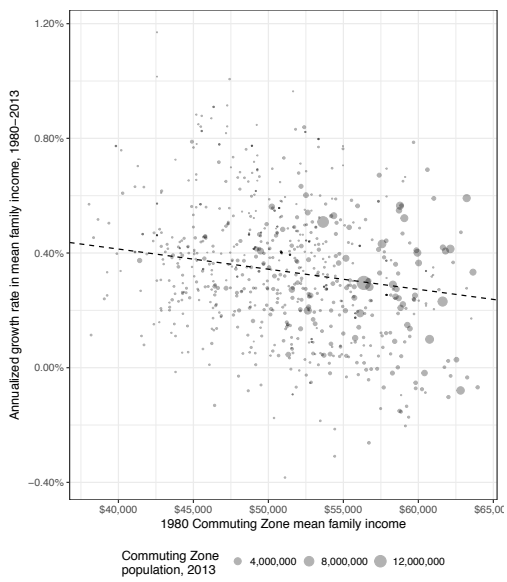

C. Richest $10 \%$ dropped

\section{$\underline{\text { Sorting and inequality as contributors to regional economic divergence }}$}

Finally I replicate my analysis of the relative importance of sorting and inequality as drivers of regional divergence. I create counterfactual income distributions for each Commuting Zone using the technique described in the main text, but here I compute the counterfactual beta divergence measures by comparing observed income in 1980 to the simulated income growth from 1980-2013 in each scenario.

Panel A of Figure A2.3 shows what beta divergence would have been had inequality remained at its 1980 level. If there had been no rise in inequality, sorting alone would have resulted in regional convergence, not divergence. This is because there was a certain amount of regional shuffling in income rank during this time. Comparing Figure A2.3A with the line for "observed geography, 1980 income" in Figure 7 of the main text, we can say that income sorting alone would have resulted in a moderate increase in the amount of dispersion across Commuting Zones from 1980-2013, but that many of the cities that had high incomes at the end of the period would be different from those who were prosperous at the beginning of the period. This can be seen by comparing the map in Panel B of Figure 8 in the main text with that in Panel B of Figure 1. If there had been no change in income sorting after 1980, Chicago, Detroit, and Houston would be among the richest cities in the country, while Boston would not. 
Figure A2.3. Simulated beta divergence in mean family income across Commuting Zones, 1980-2013, with inequality (A) and sorting (B) held constant.

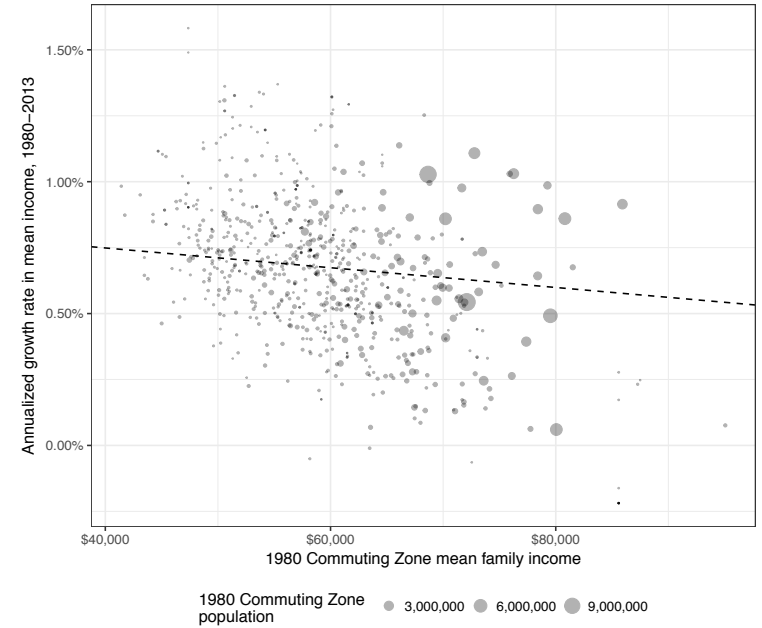

A. Inequality held constant at 1980 level

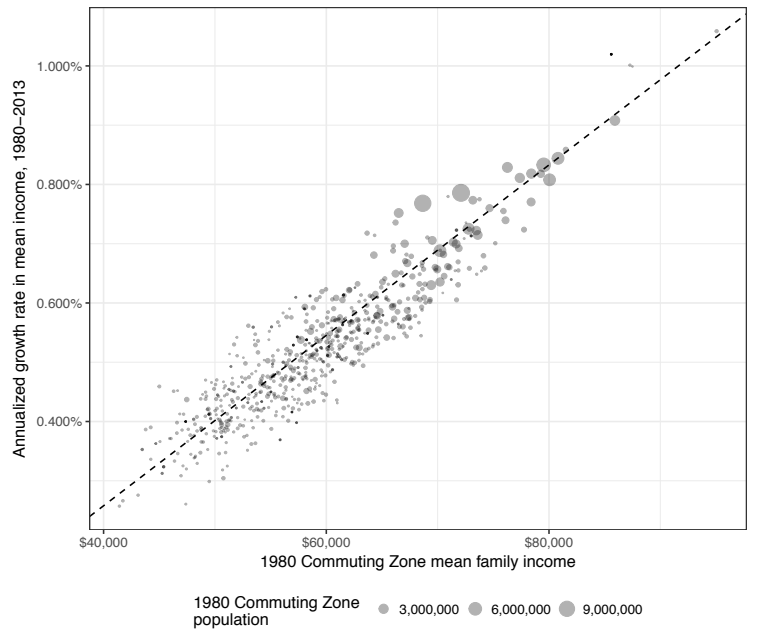

B. Sorting held constant at 1980 level

As shown in Panel B, however, the moderately converging effect of income sorting was more than negated by the strong diverging effect of rising inequality. If there had been no sorting, there would have been an almost perfect positive correlation between Commuting Zone mean family income in 1980 and growth in that measure from 1980-2013. This makes sense because without any changes to the geography of which income percentiles are found where, rising inequality would result in metropolitan income growth that was strongly correlated with initial income rank. Combining panels $\mathrm{A}$ and $\mathrm{B}$, we again see that the role of income sorting in driving divergence is much smaller than that of rising income inequality. 